Derleme/Review

\title{
Afganistan'ın Yenilenebilir Enerji Kaynaklarının Teorik Potansiyelleri ve Kullanım Kapasiteleri
}

\author{
Abdul Maroof Shirzad ${ }^{1 *}$, İsmail Tarhan ${ }^{1,2,3}$ \\ ${ }^{1}$ Çanakkale Onsekiz Mart Üniversitesi, Fen Bilimleri Enstitüsü, Enerji Kaynakları ve Yönetimi ABD \\ ${ }^{2}$ Çanakkale Onsekiz Mart Üniversitesi, Fen Bilimleri Enstitüsü, Fizik ABD \\ ${ }^{3}$ ÇOMÜ Enerji Kaynakları Araştırma ve Uygulama Merkezi (ÇEKAM) \\ 18.03.2019 Geliş/Received, 15.04.2019 Kabul/Accepted
}

\section{Özet}

Afganistan halkı dünya ölçeğinde en düşük elektrik kullanım oranına sahip olmasına rağmen yapılan çalışmalar, bu ülkenin hem önemli yenilenebilir enerji potansiyeli hem de geleneksel enerji rezervleri bakımından oldukça zengin olduğunu göstermektedir. Afganistan, doğal ve coğrafi olarak güneş, rüzgar, hidro, jeotermal ve biyokütle gibi yenilenebilir enerji kaynakları bakımından uygun coğrafi konumda olduğu için çok önemli bir ölçüde bu kaynaklardan faydalanabilir potansiyele sahiptir. Ayrıca, alternatif enerji kaynakların kullanımı için yeterli ve uygun arazilere sahip bir ülkedir. Tüm bunlara rağmen, altyapıların çoğu özellikle ulusal şebekeler, son birkaç on yıl içinde ülkedeki savaş ve istikrarsızlık sırasında tahrip edilmiştir. Bu nedenle, Afganistan elektrik ihtiyacını çoğunlukla Türkmenistan, Özbekistan, Tacikistan ve İran gibi komşu ülkelerden ithal etmektedir. Afganistan'daki Enerji ve Su Bakanlığı'nın (ESB) liderliği altında elektrik üretimi ile ilgili çalışmakta olan şubeler ve kamu sektörlerine göre, ülkede hidroelektrik sistemi hariç, yenilenebilir enerji kaynakları için şebeke ölçeğinde bir sistem bulunmamasına rağmen, bu kaynaklarla ilgili birçok proje çalışması yapılmaktadır. Teorik açıdan, Afganistan'da yenilenebilir enerjinin kullanımı, çoğunlukla kırsal bölgelerde yaşayan Afgan halkı için sadece sürdürülebilir bir enerjinin sağlanmasına değil, ayrıca ülkede sürdürülebilir ekonomik kalkınmaya katkı sağlayacaktır. Bu çalışmanın temel amacı diğer kaynaklardan da faydalanarak Afganistan'daki yenilenebilir enerji kaynaklarının teorik potansiyellerini, mevcut ve gelecekteki kullanım kapasitelerini derleyerek, irdelemeye ve tartışmaya çalışmaktır.

Anahtar Kelimeler: Afganistan, alternatif enerji kaynakları, elektrik şebekeleri, yenilenebilir enerji.

\section{Theoretical Potentials and Utilization Capacities of Afghanistan's Renewable Energy Resource}

\begin{abstract}
\footnotetext{
*Sorumlu Yazar (Corresponding Author): Abdul Maroof Shirzad (e-posta:abdulmaroofshirzad@gmail.com)

Bu makale Abdul Maroof Shirzad'ın tez konusu kapsamında yazılmıştır.
}

Afghanistan is one of the countries where its population has the lowest access to electricity in the world although the studies show that it is rich in both significant renewable energy 
potential and conventional energy reserves. Since Afghanistan has adequate natural and geographical conditions, it can benefit significantly from renewable energy resources such as hydro, solar, geothermal, biomass, wind and biomass. Even though Afghanistan has enough areas for utilization of alternative resources, most of the infrastructures (particularly national grids) were destroyed during the last decades because of war and instability. Therefore, the majority of electricity demands are imported from central Asian countries and Iran. This cause higher cost for energy, and other problems as well. According to public sector organizations and departments under leadership of the Ministry of Energy and Water of the country, although Afghanistan does not have any network system for renewable energy excluding hydropower system, does not have any network system, so many projects have been done in this regard. From the theoretical point of view, utilization of renewable energy in Afghanistan can play a very important role (especially in the rural areas where majority of Afghan Nation live there) not only to supply sustainable energy for its population but also it contributes for sustainable economic development. The main purpose of this study is to attempt to compile, examine and discuss the theoretical potential, current and future use capacities of renewable energy sources in Afghanistan by considering other studies.

Keywords: Afghanistan, alternative energy resources, electricity networks, renewable energy.

\section{Giriş}

Günümüzde yenilenebilir enerji kaynakları; çevre dostu olması yanında ekonomik büyümeye ve sosyal-toplumsal gelişmeye katkılar sağlaması nedeniyle, özellikle elektrik üretim konusunda diğer kaynaklara göre daha fazla dikkat çekmektedir. Bölgedeki ülkelerin küresel elektrik şebekesine erişimleri karşılaştırıldığında, Afganistan halkı dünya ölçeğinde en düşük elektrik kullanım oranına sahip olmasına rağmen yapılan çalışmalar, bu ülkenin hem önemli yenilenebilir enerji potansiyeli hem de geleneksel enerji rezervleri bakımından oldukça zengin olduğunu göstermektedir. Peştun aşiretlerini bir araya getiren Ahmed Şah Durrani tarafından 1747 yılında kurulan ve 08 Ağustos 1919 tarihinde bağımsızlığına kavuşan Afganistan, coğrafi olarak doğuda $60^{\circ} 31^{\prime}$ ve $75^{\circ} 00^{\prime}$ ile kuzeyde $29^{\circ} 35^{\prime}$ ve $38^{\circ} 40^{\prime}$ arasında yer almaktadır. Asya kıtasının Güney-Orta Asya kısmında yer almakta; dağlı, karasal ve denize sınırı olmayan bir konumda bulunmaktadır (Ershad, 2017). Afganistan, batı taraftan 936 km'lik sınırı ile İran'la, güney doğu'dan 2.430 km'lik sınırı ile Pakistan'la, kuzey doğu'dan 76 km'lik sınırı ile Çin'le, kuzey'den 1.206 km'lik sınırı ile Tacikistan, 137 km'lik sınırı ile Özbekistan ve 744 km'lik sınırı ile Türkmenistan olmak üzere komşuları ile toplam sınır uzunluğu $5.529 \mathrm{~km}$ dir (Anonim, 2017a). Doğu ve batı arasındaki önemli yolların kesişme noktalarında bulunan Afganistan, stratejik konumundan dolayı tarih boyunca Arapların, Yunanlıların, Türklerin, Sovyetlerin, Moğolların, İranlıların ve İngilizlerin çeşitli saldırılarına maruz kalmıştır (Anonim, 2019a). Hindistan ile Çin'i birbirine bağlayan ve uluslararası öneme sahip enerji koridoru üzerinde yer almasıyla stratejik ülke konumunda olan Afganistan'in gelişmesi bu saldırılar nedeniyle uzun yıllar boyunca engellenmiştir (Anonim, 2017b). Bu durum özellikle berilyum, altın, gümüş, krom, kurşun, çinko, bakır, demir, tuz, mermer, klinker, kil, kireç taşı yataklarına ek olarak kömür, doğalgaz ve petrol gibi zengin maden kaynakları yanında zengin hidroenerji, jeotermal, güneş ve rüzgar enerji potansiyellerinin gerektiği gibi kullanılamamasında kendini göstermiştir (Anonim, 2019a, Anonim 2019b; Anonim, 2109c). Ülkenin toplam yüzölçümü 652.864 km² olup, kurak ve yarı kurak bozkır bir iklime sahip, dolayısı ile yazları sıcak ve kışları çok soğuktur (Ludin ve ark, 2017a; Ludin ve ark., 2017b; Ershad, 2017; Anonim, 2017a). Nüfusu yaklaşık 33.000.000'un üzerinde olan Afganistan'da, 2004 yılı verilerine göre nüfusun yaklaşık yarıya yakını iş 
gücüne katk1 sağlamakta ve iş gücünün \%80'i tarım, \%10’u endüstri yanında \%10'u da hizmet sektöründe çalışmaktadır (Anonim, 2017b; Anonim, 2018a; Anonim, 2019a). Çeşitli kaynaklarda (Anonim, 2019a; Anonim, 2019d; Anonim, 2019e) nüfus artış oranı'nın (Çizelge 1.1 ve Şekil 1.1) tahminen \% 2,67 olduğu belirtilen Afganistan'ın yıllık elektrik üretiminin yaklaşı $900 \mathrm{GWh}$ civarında, elektrik tüketiminin ise $1000 \mathrm{GWh} / \mathrm{y} 1 \mathrm{l}$ değerini aştığı ve bu nedenle her yıl $200 \mathrm{GWh}$ aşan değerlerde elektrik enerjisi ithal etmek zorunda kaldığı ifade edilmektedir. Birkaç on yıl içinde, bu ülke yaşadığı savaşlar ve savunmasızlıktan dolayı güvensiz bir hale gelmiştir. Birleşmiş Milletler İnsani Gelişme Endeksi'ne göre Afganistan, 2012 yılında 175. sırada yer alırken 2017 yılında 168. sıraya yükselmiştir (Ershad, 2017; Anonim, 2018b). Ershad (2017)'ye göre Afganistan'da, 2008 y1lı nüfusunun işsizlik oranı $\% 35$ ve fakirlik koşullarında yaşayanların oranının ise \%36 olduğu belirtilmiştir. Bu durum Afganistan'daki halkın büyük çoğunluğunun elektrik şebekelerinden yararlanamamasına neden olmaktadır. Ershad (2017) tarafından yapılan bir çalışmada; Afganistan'da 2010 yılında okuryazarlık oranı yaklaşık \%30 civarında iken, 2015 yılında bu değerin \%50 civarında olduğu ifade edilmiştir. Birleşmiş Milletler Kalkınma Programı (BMKP)'nin 2013 yılındaki bir araştırmasında, gayri safi yurtiçi üretimin \%33'ü ülkedeki tarımdan karşılandığ 1 ve tarım ülkesi olan Afganistan'da istihdamın \%78,6'sının tarım alanında olduğu belirtilmiştir (Anonim, 2015). Afganistan'daki orman örtüsü son otuz yılda \%50 oranında azalmıştır. 2013 yılında yapılan BMKP anketine göre, ülkenin yalnızca \%2'si ormanlarla kaplıdır (Musleh, 2016). Afganistan Enerji ve Su Bakanlığı (AESB)'nın da yer aldığı çeşitli çalışmalarda; 2003 yılında Afganistan'ın nüfusunun yalnızca $\% 7$ oranında elektrik şebekesiyle bağlantısı olduğu, ancak bu oranın 2009 yılında \%10 - 15 arasında, 2014 yılında \%26 ve 2016 y1llı için ise \%30 civarında olduğu ifade edilmiştir (Ashraf, 2009; Alamyar, 2014; Anonim, 2014a; Ershad, 2017). Ershad (2017)'ye göre; Afganistan'da 2032 y1lına kadar ulusal elektrik şebekesine ulaşım oranının \% 83'lere ulaşacağı ön görülmektedir. Ershad (2017)'de belirtildiği üzere Dünya Bankası tarafından yapılan bir çalışmaya göre, Afganistan'daki nüfusun yaklaşık $\% 77$ 'si kırsal alanlarda yaşamaktadır, bu nüfusun sadece \%11'i ulusal sistemlerden elektrik sağlamaktadır, \%85'inden fazlası ise geleneksel biyokütle (özellikle odun ve gübrelerden) kullanarak enerji taleplerini karşılamaktadır ve bu yakıtlar özellikle pişirme ve ısıtma işleri için doğrudan kullanmaktadır. Diğer taraftan, Ershad (2017) tarafından da vurgulandığı gibi; Afganistan nüfusunun \%23'ü kentsel alanlarda Kabil, Kandahar, Herat ve Mezar Şerif gibi büyük şehirlerde yaşamaktadır ve bunların \%90'ından fazlası şebeke elektrik sisteminden elektrik almaktadır. Yapılan çalışmada; Afganistan'da, 2013 yılında brüt elektrik enerjisi tüketiminin kişi başına $178 \mathrm{kWh}$ ve yıllık bürüt talebin $3.531 \mathrm{GWh}$ olarak gerçekleştiği, 2032 yılına kadar toplam brüt talebin yıllık ortalama $18.409 \mathrm{GWh}$ 'lık talebin beklendiği tahmin edilmekte olduğu belirtilmiştir (Ershad, 2017). Bu nedenle, büyümenin de getirdiği gereksinimler sonucu, Afganistan'ın 2013 yılında ürettiği enerjinin yaklaşık 5 katı daha fazla elektrik enerjisine ihtiyaç duyulmaktadır. 2013 yılında Afganistan'ın toplam nüfusunun yaklaşık \% 24'ü elektrik şebekesinden elektrik alırken, bu rakamın 2032 yılına kadar yaklaşık \% 83 oranında artması beklenilmektedir (Ershad, 2017; Ludin ve ark., 2017a,b). Bu çalışmalarda; 2013 yılında Afganistan halkının \%25'ten az bir kesimin elektrik şebekesine erişimi var iken, 2020 yılında erişimin \%50’ye çıkmasının beklendiği belirtilmektedir. 
Çizelge 1.1. Yıllara göre Afganistan nüfusu ve yıllara göre değişimi (Anonim, 2019e; Anonim, 2019f'den uyarlanmıştır)

\begin{tabular}{|c|c|c|c|c|c|}
\hline Y1l & Toplam Nüfus & Artış Yüzdesi & Y11 & Toplam Nüfus & Artış Yüzdesi \\
\hline 2016 & 27.657 .145 & $\uparrow \% 2,05$ & 1988 & 11.013 .345 & $\downarrow \% 0,45$ \\
\hline 2015 & 27.101 .365 & $\uparrow \% 2,05$ & 1987 & 11.063 .107 & $\downarrow \% 1,77$ \\
\hline 2014 & 26.556 .754 & $\uparrow \% 2,05$ & 1986 & 11.262 .439 & $\downarrow \% 2,31$ \\
\hline 2013 & 26.023 .100 & $\downarrow \% 12,75$ & 1985 & 11.528 .977 & $\downarrow \% 2,74$ \\
\hline 2012 & 29.824 .536 & $\uparrow \% 2,47$ & 1984 & 11.854 .205 & $\downarrow \% 3,17$ \\
\hline 2011 & 29.105 .480 & $\uparrow \% 2,49$ & 1983 & 12.241 .928 & $\downarrow \% 3,11$ \\
\hline 2010 & 28.397 .812 & $\uparrow \% 2,49$ & 1982 & 12.634 .494 & $\downarrow \% 2,54$ \\
\hline 2009 & 27.708 .187 & $\uparrow \% 2,50$ & 1981 & 12.963 .788 & $\downarrow \% 1,64$ \\
\hline 2008 & 27.032 .197 & $\uparrow \% 2,59$ & 1980 & 13.180 .431 & $\downarrow \% 0,58$ \\
\hline 2007 & 26.349 .243 & $\uparrow \% 2,80$ & 1979 & 13.257 .128 & $\uparrow \% 0,44$ \\
\hline 2006 & 25.631 .282 & $\uparrow \% 3,10$ & 1978 & 13.199 .597 & $\uparrow \% 1,27$ \\
\hline 2005 & 24.860 .855 & $\uparrow \% 3,51$ & 1977 & 13.034 .460 & $\uparrow \% 1,78$ \\
\hline 2004 & 24.018 .682 & $\uparrow \% 3,90$ & 1976 & 12.806 .810 & $\uparrow \% 2,03$ \\
\hline 2003 & 23.116 .142 & $\uparrow \% 4,11$ & 1975 & 12.551 .790 & $\uparrow \% 2,27$ \\
\hline 2002 & 22.202 .806 & $\uparrow \% 4,01$ & 1974 & 12.273 .589 & $\uparrow \% 2,57$ \\
\hline 2001 & 21.347 .782 & $\uparrow \% 3,65$ & 1973 & 11.966 .352 & $\uparrow \% 2,77$ \\
\hline 2000 & 20.595 .360 & $\uparrow \% 3,04$ & 1972 & 11.644 .377 & $\uparrow \% 2,83$ \\
\hline 1999 & 19.987 .071 & $\uparrow \% 2,51$ & 1971 & 11.323 .446 & $\uparrow \% 2,79$ \\
\hline 1998 & 19.496 .836 & $\uparrow \% 2,50$ & 1970 & 11.015 .621 & $\uparrow \% 2,67$ \\
\hline 1997 & 19.021 .226 & $\uparrow \% 3,29$ & 1969 & 10.729 .191 & $\uparrow \% 2,52$ \\
\hline 1996 & 18.415 .307 & $\uparrow \% 4,72$ & 1968 & 10.465 .770 & $\uparrow \% 2,39$ \\
\hline 1995 & 17.586 .073 & $\uparrow \% 6,68$ & 1967 & 10.221 .902 & $\uparrow \% 2,32$ \\
\hline 1994 & 16.485 .018 & $\uparrow \% 8,63$ & 1966 & 9.990 .125 & $\uparrow \% 2,31$ \\
\hline 1993 & 15.175 .325 & $\uparrow \% 9,87$ & 1965 & 9.765 .015 & $\uparrow \% 2,28$ \\
\hline 1992 & 13.811 .876 & $\uparrow \% 9,51$ & 1964 & 9.547 .131 & $\uparrow \% 2,22$ \\
\hline 1991 & 12.612 .043 & $\uparrow \% 7,51$ & 1963 & 9.339 .507 & $\uparrow \% 2,16$ \\
\hline 1990 & 11.731 .193 & $\uparrow \% 4,60$ & 1962 & 9.141 .783 & $\uparrow \% 2,10$ \\
\hline \multirow[t]{2}{*}{1989} & 11.215 .323 & $\uparrow \% 1,83$ & 1961 & 8.953 .544 & $\uparrow \% 2,04$ \\
\hline & & & 1960 & 8.774 .440 & \\
\hline
\end{tabular}

Afganistan'1n Enerji Hizmetleri Kanunu, Ulusal Enerji Politikası ve Ulusal Yenilenebilir Enerji Politikası'nın temel amacı, ülkenin elektrik talebinin \%95'ini 2032 yılına kadar yenilenebilir enerji kaynaklarından üretmek olduğu ifade edilmektedir (Ershad, 2017). Şekil 1.2 'de görüldüğ̈̈ gibi, Afganistan şu anda elektrik talebinin \%60'1nı Özbekistan, Türkmenistan ve Tacikistan gibi Orta Asya ülkelerinden ve İran'dan ithal ederken, ülkenin enerji ihtiyacının \%40'1 yerli üretimden karşılanmaktadır (Anonim, 2017c; Anonim, 2017d; Anonim, 2017e). Şekil 1.3'de gösterildiği gibi, yerli üretimin \%44'ü hidroelektrik santrallerden elde edilirken, \%41'i termik santrallerden ve \%15'i dizel jeneratörlerden sağlanmaktadır (Anonim, 2017c). Ancak, toplam 51,5 MW'1n 37 MW'1 mikro hidroelektrik santrallerinden ve 14,5 MW'1 ise fotovoltaik güneş enerjisinden olacak şekilde projelendirilmektedir. Bunlar Şekil 1.3'deki yüzdeye dahil değildir. Afganistan'ın mevcut arz ve tahmini elektrik talebi, 2007 yılından 2020 yılına kadar Şekil 1.4'te verilmektedir 
(Alamyar, 2014). Afganistan'da sektörlere göre 2013, 2014 ve 2015 y1lları için enerji kullanımı Şekil 1.5'te ve 2015 yılı için elektrik kullanım yüzdesi sektörlere göre Şekil 1.6'te gösterilmektedir (Anonim, 2017c).

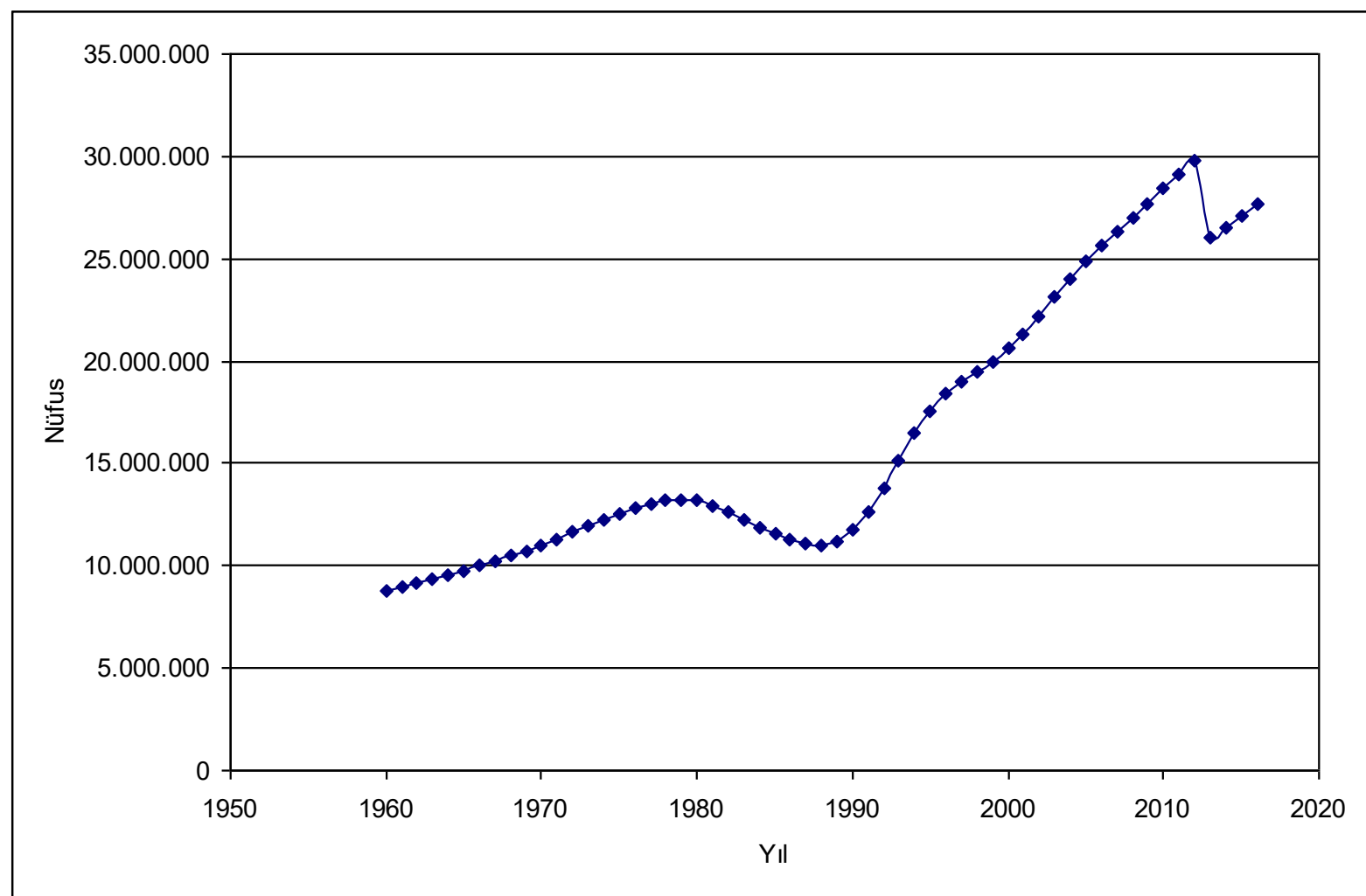

Şekil 1.1. Afganistan nüfusunun y1llara göre değişimi (Anonim 2019d; Anonim, 2019e; Anonim, 2019f'den uyarlanmıştır)

$\mathrm{Bu}$ çalışmanın temel amacı; yapılan çeşitli çalışmaları birlikte değerlendirerek, Afganistan'daki güneş, rüzgar, hidrolik, biyokütle ve jeotermal gibi yenilenebilir enerji kaynakların teorik potansiyelini incelemek, mevcut ve gelecekteki kullanımlarını irdelemek, bu kaynakların Afganistan gibi bir ülke için ne kadar önemli ve faydalı olduğunu vurgulamak olarak özetlenebilir.

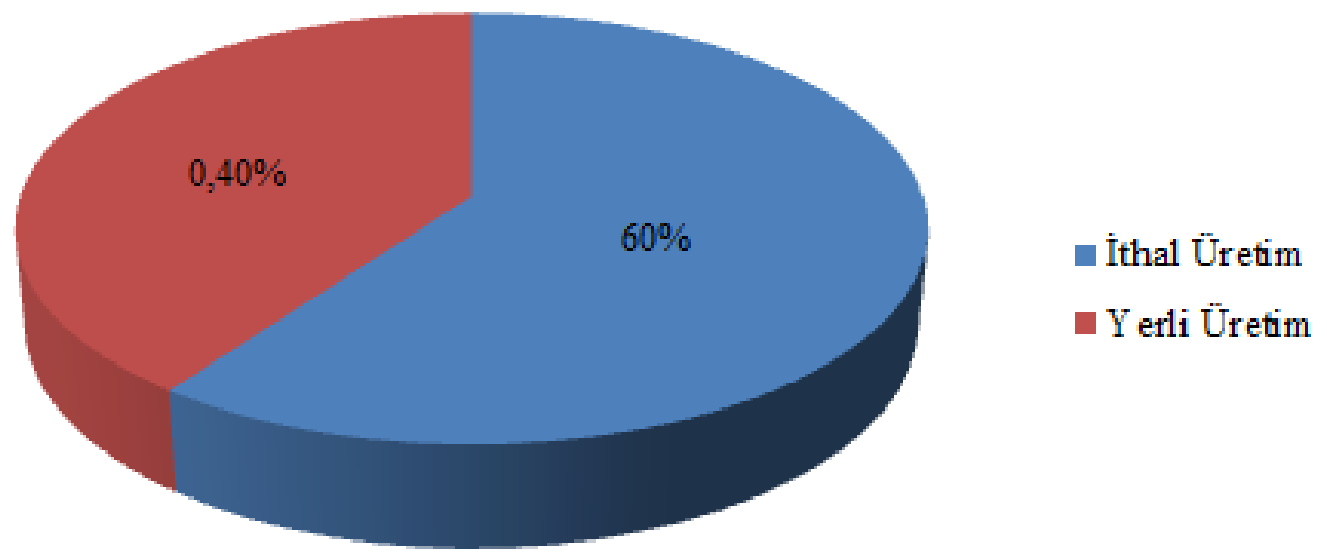

Şekil 1.2. Afganistan'ın mevcut elektrik üretim dağılımı (Anonim, 2017c'den uyarlanmıştır) 


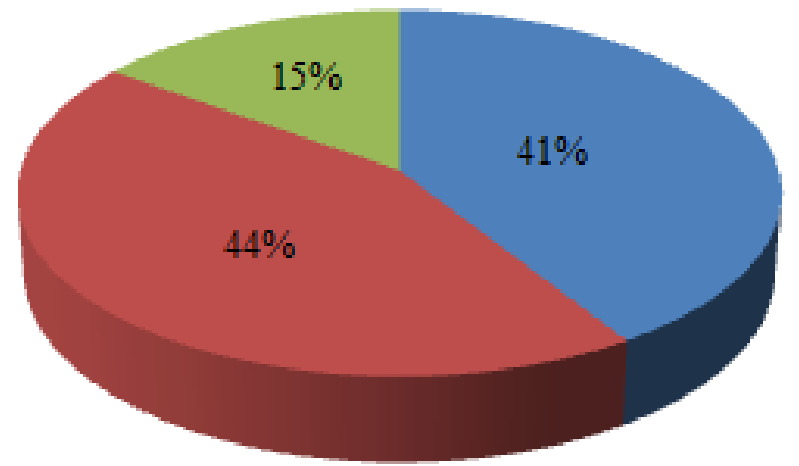

- Termik Elektrik Santrali

- Hidro Elektrik Santrali

Dizel Jeneratör

Şekil 1.3. Afganistan'ın mevcut yerli elektrik üretim durumu (Anonim, 2017c'den uyarlanmıştır).

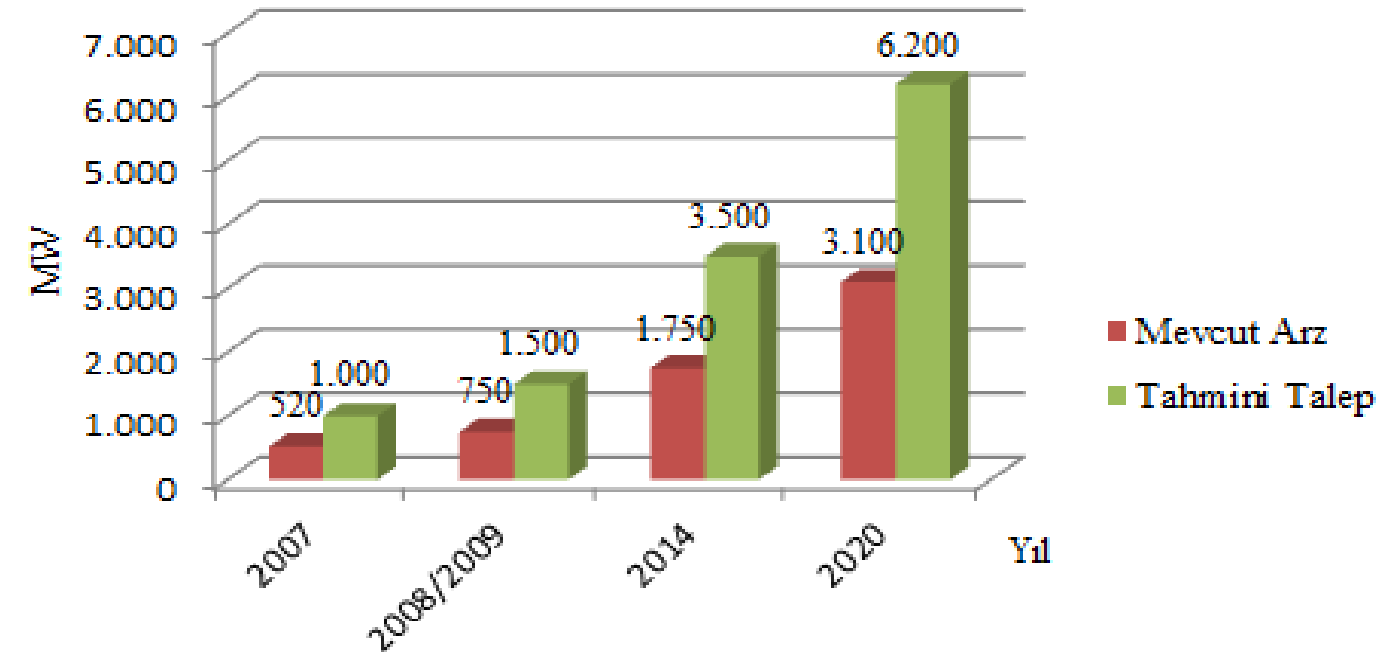

Şekil 1.4. Yillara göre Afganistan'daki mevcut arz ve tahmini talep elektrik (Alamyar, 2014'den uyarlanmıştır).

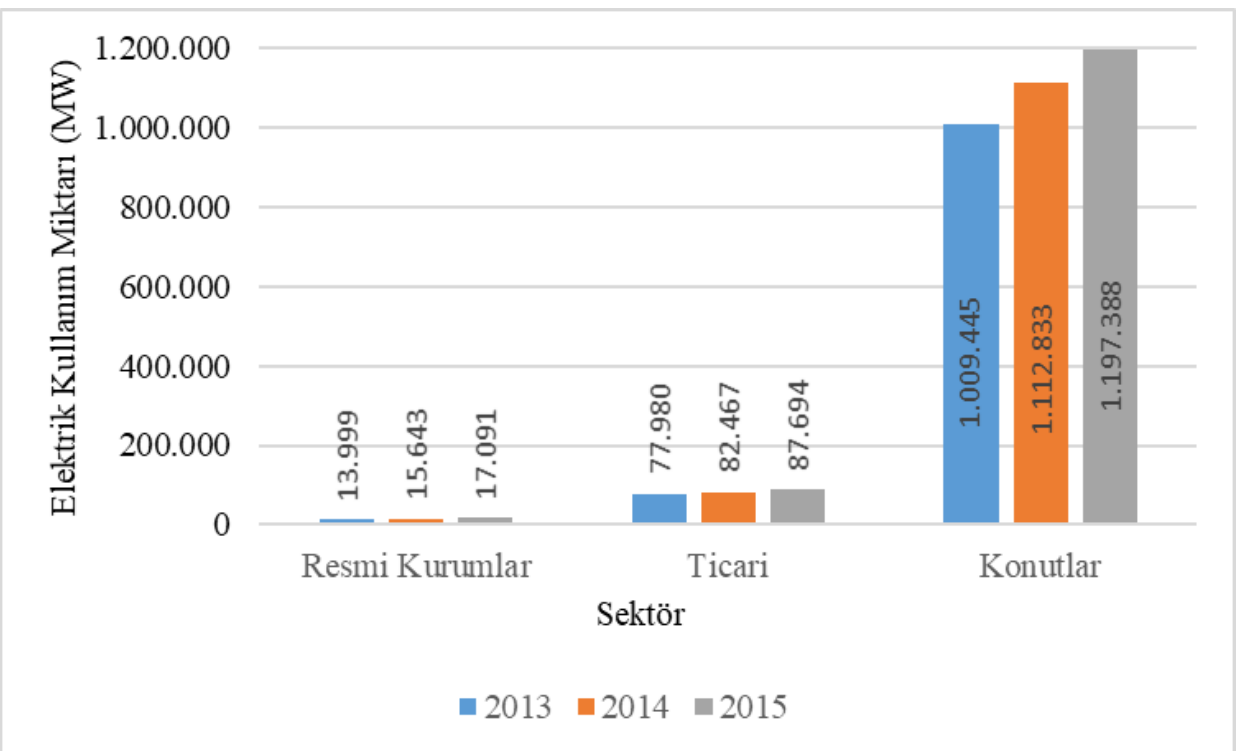

Şekil 1.5. Afganistan'da yıllara göre devlet kurumları, ticari alanlar ve binalar gibi sektör başına elektrik kullanım miktarı (Anonim, 2017c'den uyarlanmıştır). 
Sektörlere Göre Elektrik Kullanım Yüzdeleri

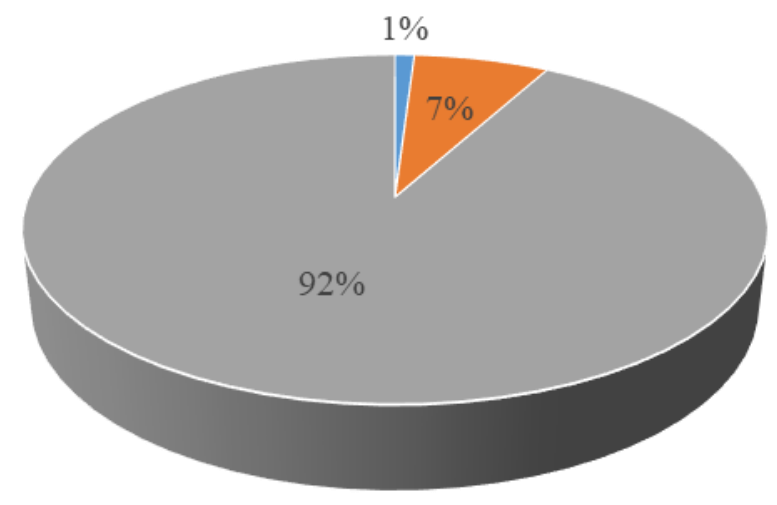

- Resmi Kurumlar $\quad$ - Ticari $\quad$ - Konutlar

Şekil 1.6. Afganistan'da 2015 yılı sektörlere göre elektrik kullanım yüzdesi (Anonim, 2017b'den uyarlanmıştır).

\section{Afganistan'daki Enerji Çalışmaları ve Destekler}

Afganistan'da Enerji ve Su Bakanlığı (ESB), Kırsal Rehabilitasyon ve Kalkınma Bakanlığı (KRKB) ve Da Afganistan Breşna Şerkat (DABŞ) gibi bakanlıklar ve kurumlar ülkenin enerji sektörünün gelişim konusunda üç ana kamu kuruluşu olarak rol oynamaktadır. Enerji ve Su Bakanlığı, hem kırsal ve hem de kentsel alanlar dahil olmak üzere enerji sektörünün gelişimin ana sorumlusudur. Örneğin; ESB ülkenin elektrik sektöründe, sektör planlarının tasarımı dahil olmak üzere kurumsal olarak tüm politika ve düzenlemelerinin şekillendirilmesinden sorumludur. Enerji ve Su Bakanlığı, enerji ve su sektörlerinin gelişmesini yönlendirmek ve onları devlet tarafından oluşturulan kararı alma süreçlerini getirmektedir. Ayrıca, kamu ve özel paydaşları, politikaları ve stratejileri uygulama konusunda teşvik etmeye çalışmaktadır. Ayrıca, bazı bölümler ve kamu sektörü kuruluşları veya yenilenebilir enerji bölümü ve yenilenebilir enerji koordinasyon komitesi gibi koordinasyonlar, ülkedeki enerjiyi geliştirmek için Enerji ve Su Bakanlığı'nın liderliği altında farklı görevleri yapmak için çalışmaktadır (Anonim, 2017b). Öte yandan, KRKB'nın görevi sadece ilçelere ve köylere yardım götürmek olup, etkisi ilçeler ve köylerle sınırlıdır. KRKB'nın işlevi ise, tarımsal faaliyetler hariç, kırsal alanlarda sosyal ve finansal büyümeyi arttırmaktır. Böylece yoksulluğun azaltılması ve kırsal alanlardaki insanların yaşam koşullarının iyileştirilmesi hedeflenmektedir. Bu amaçla KRKB, yenilenebilir enerji kaynaklarından elektrik arzı ile ilgili bazı programlar uygulamıştır ve yeni proje çalışmaları da sürmektedir. Ayrıca; Afganistan Kırsal Kalkınma için Sürdürülebilir Enerji (AKKSE) çalışma birimi, KRKB liderliği altında çalışmalarını sürdürmektedir. Bu birimin görevi özellikle kırsal alanlarda sürdürülebilir enerjinin kullanımını sağlamak ve geliştirmektir. Afganistan'da elektrik enerjisi üzerine yatırımları organize eden ve işleri yürüten DABŞ, Afganistan'daki devlete ait \%100 yardımcı kurumdur. Bu kurumun görevi elektrik üretimi, tesis operasyonu ve ulusal şebeke ve dağıtım şebekelerinin bakımını sağlamak ve yeni projeler gerçekleştirmektir. Yeni yürürlüğe giren 'Güç Hizmetleri Yönetmeliği Yasası' 'na göre, özel şirketler elektrik üretimine ve dağıtımına yatırım yaparak Afganistan Enerji ve Su Bakanlığı'ndan lisans alabilmektedir. Nisan 2017'ye kadar sekiz özel şirket lisansı almıştır (Anonim, 2017b; Alamyar, 2014; Ludin ve ark., 2017a). Şekil 2.1'de Afganistan'daki genel elektrik tüketim durumu gösterilmektedir. Asya Kalkınma Bankası 
(AKB), Birleşmiş Milletler Çevre Programı (BMÇP), Birleşmiş Milletler Kalkınma Programı (BMKP), Amerika Birleşik Devletleri Ajansı Uluslararası Kalkınma (ABDAUK) için, Afganistan'da Enerji Kurumsal Gelişmesi (AEKG) ve Dünya Bankası (DB) gibi uluslararası kuruluşlar, Afganistan'ın enerji sektöründe etkin olan ana finansal kuruluşları ve destekçileridir (Anonim, 2017b).

\section{Afganistan'ın Elektrik Şebeke Sistemi}

Afganistan'da hidroelektrik şebeke sistemi hariç, şu ana kadar yenilenebilir enerji üretimi ile bağlantılı bir şebeke sistemi yoktur. Ancak bazı yerleşim yerlerinin elektrik ihtiyacının karş1lanabilmesi için fotovoltaik güneş panelleri kurularak bireysel kullanımlara yönelik birkaç yerel elektrik üretim uygulamaları yapılmıştır. Diğer taraftan, tüm elektrik şebekelerinin birbirine bağlanması 2032 yılına kadar öngörülmektedir (Ershad, 2017). Afganistan, özellikle güneş, rüzgar, hidro, biyokütle ve jeotermal olmak üzere yenilenebilir kaynaklar bakımından zengin olan bir ülkedir. Halbuki bu ülke şu anda elektrik talebinin büyük bir kısmını komşu ülkelerden ithal ederek ve diğer kısmını da hidroelektrik santralleri, termik santralleri ve dizel jeneratörleri gibi elektrik üretimini kurarak mevcut elektrik talebini karşılamaktadır (Ludin ve ark., 2017a). Afganistan'ın üretim, iletim, ve dağıtım gibi elektrik altyapıların çoğu son 30 yıldaki savaş ve çatışma nedeniyle tahrip olmuş ve yıkılmıştır (Alamyar, 2014). Afganistan'ın elektrik sistemi dört farklı şebekeye ayrılmaktadır. Birleşmiş Milletler Avrupa Ekonomik Komisyonun (BMAEK) raporuna göre, Afganistan'ın Kuzey Doğu Şebeke Sistemi (KDGS); Özbekistan ve Tacikistan'1 Kabil, Mazari - Şerif, Celalabad, vb ile birleştirirken Güney Doğu şebeke Sistemi; Kajaki ile kandahar, vb bağlar, Herat Şebeke Sistemi (HGS) ise; Herat bölgesi ile İran ve Türkmenistan'ı bağlar ve Türkmenistan Şebeke Sistemi de; Herat, Faryab, Sari - Pul ve Jawzjan gibi illerin Türkmenistan ile bağlantısını sağlar (Anonim, 2016). Son zamanlarda, Afganistan elektrik talebinin 345 MW'lık kısmını Özbekistan'dan, 350 MW'ını Tacikistan'dan, 300 MW'nı Türkmenistan'dan, 180 MW'nı İran'dan ithal edilmektedir (Alamyar, 2014; Amonim, 2014b; Samadi, 2011). Yerli hidroelektrik santrallerden 196 MW'lık kapasite, termik santrallerden 248 MW'lık, dizel jeneratörlerden 93 MW'llk kapasite üretilmektedir (Anonim, 2017b; Anonim, 2018b). Afganistan'daki genel elektrik tüketim durumu Şekil 3.1'de verilmiştir.

Afganistan'ın yerli hidroelektrik santralleri çoğunlukla Kabil'de Naghlu, Mahiper ve Sarobi gibi bölgelerinde, Herat bölgesinde ise Selma'da yoğunlaşmışken, termik santraller ise çoğunlukla Tarakhil ve Kuzey - Batı Kabil'de bulunmaktadır (Ludin ve ark, 2017a; Alamyar, 2014). Şekil 3.2'de Afganistan ile Türkmenistan, Özbekistan ve Tacikistan gibi Orta Asya ülkelerin ve İran'ın bağlantı hatlarını göstermektedir. Şekil 3.3'de yerli hidroelektrik santrallerinin konumu belirtilmektedir (Alamyar, 2014). Afganistan'ın Ana Güç Sektör Planı'na göre, Şekil 3.4'ten de görüleceği gibi ülkenin büyük bir kısmına elektrik şebekesinin ulaştırılabilmesine yönelik çalışmaların önümüzdeki 20 yıl boyunca süreceği tahmin edilmektedir. 


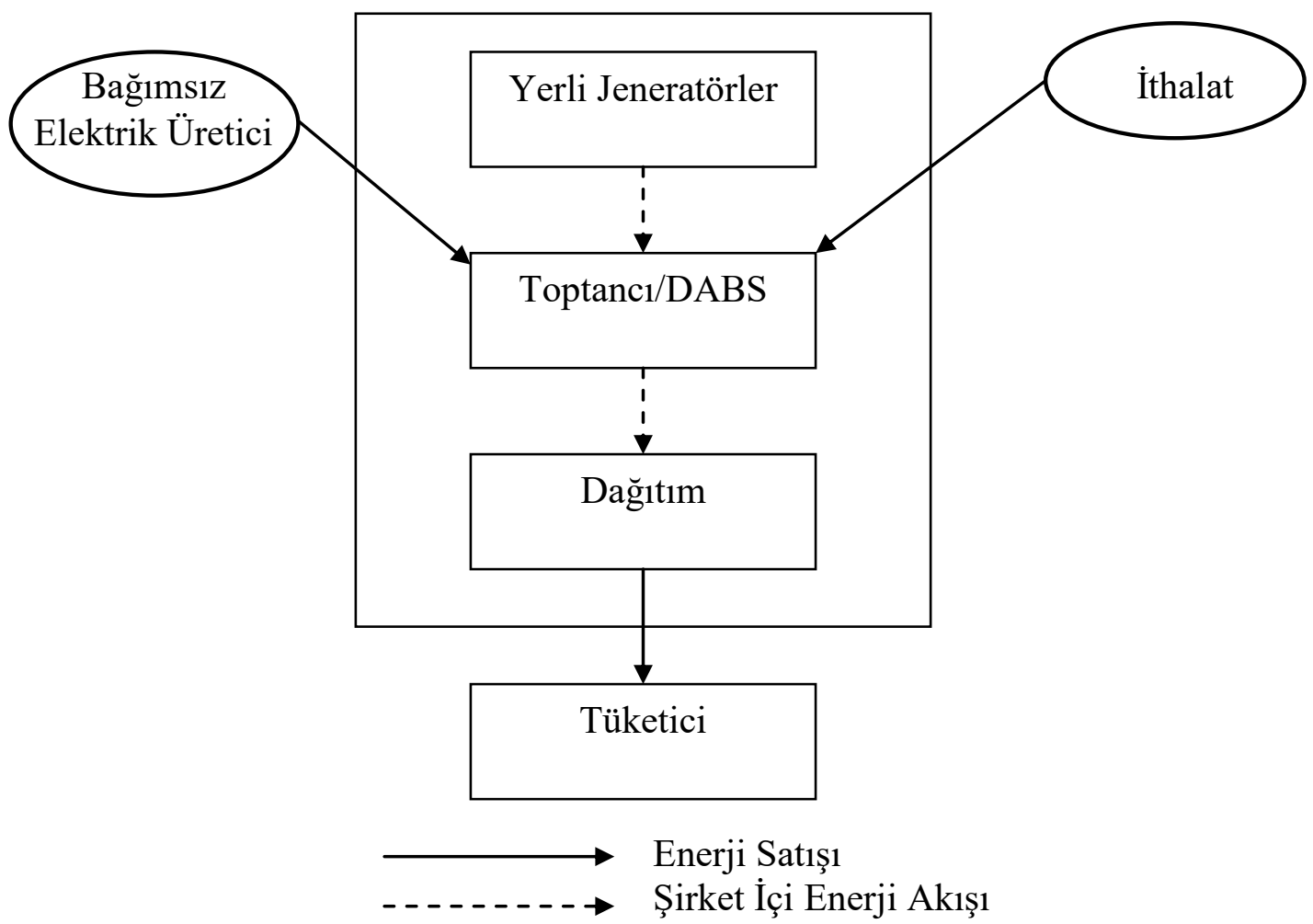

Şekil 3.1. Afganistan'daki genel elektrik tüketim durumu (Ludin ve ark, 2017b'den uyarlanmıştır).

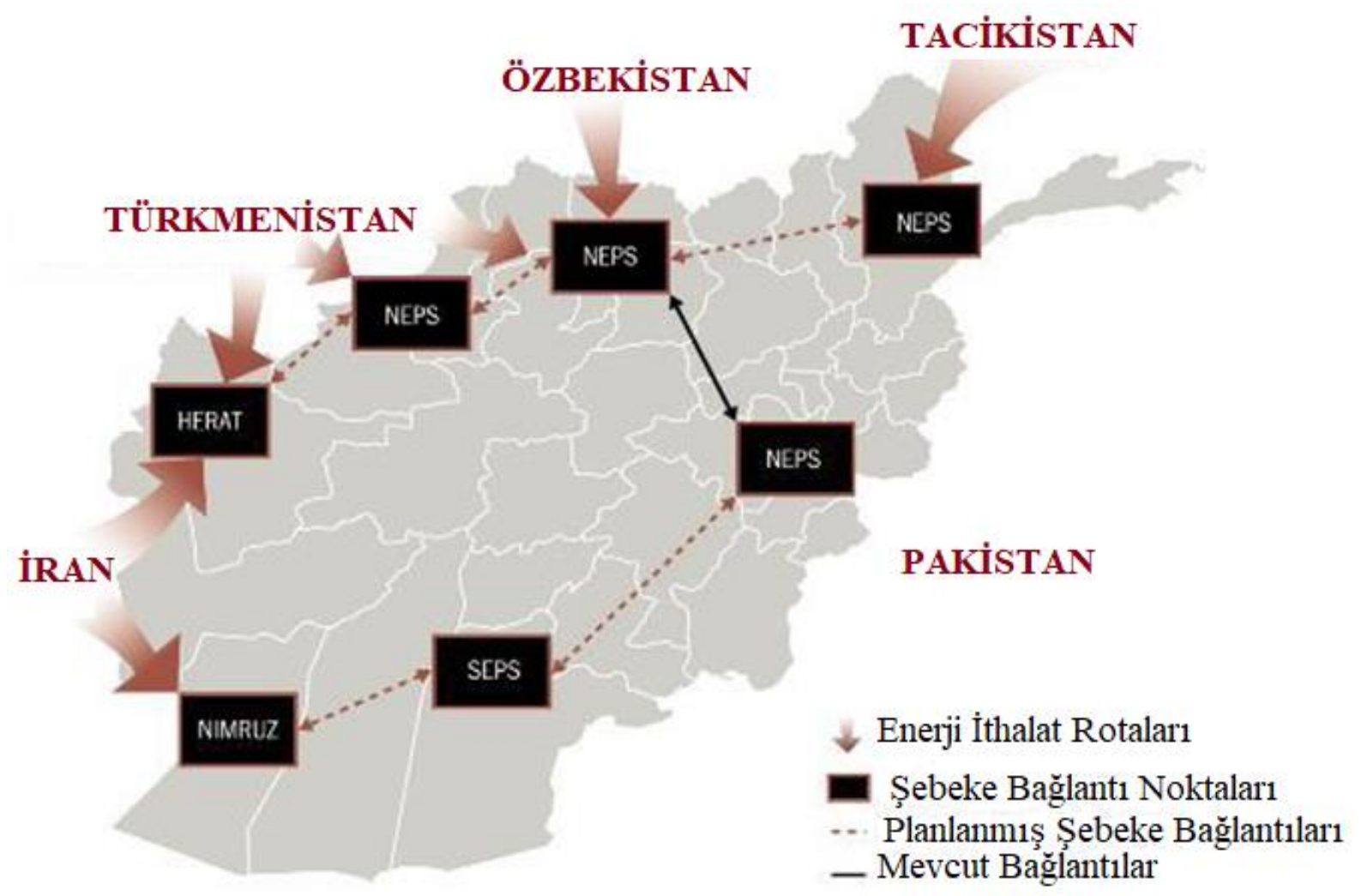

Şekil 3.2. Afganistan ve komşu ülkelerin arasındaki şebeke bağlantı hatları (Anonim, 2016'dan uyarlanmıştır). 


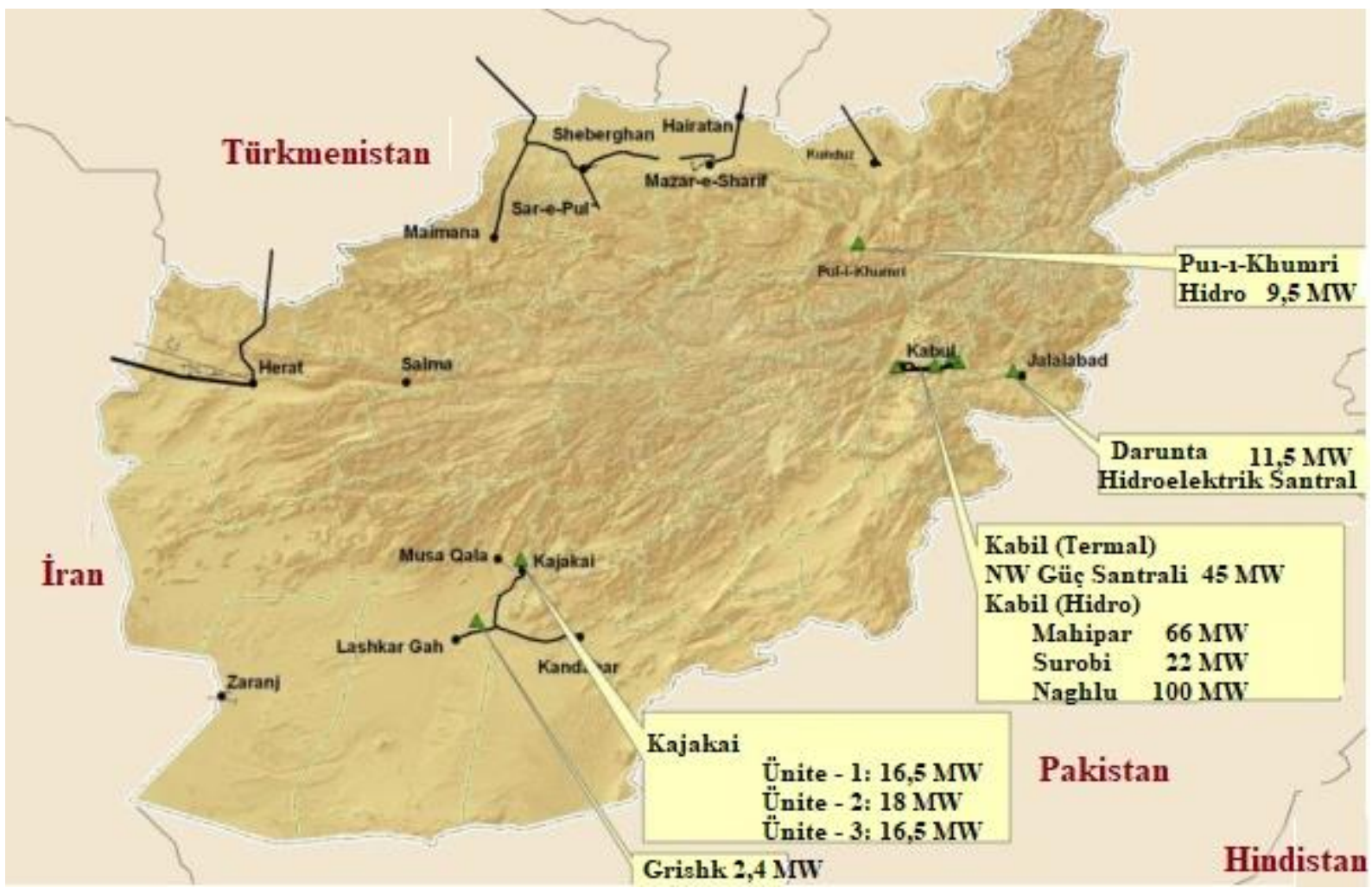

Şekil 3.3 Yerli hidroelektrik santrallerinin konumu (Alamyar, 2014'den uyarlanmıştır).

\section{0 yildır şebeke bağlantısından mahrum bölgeler}

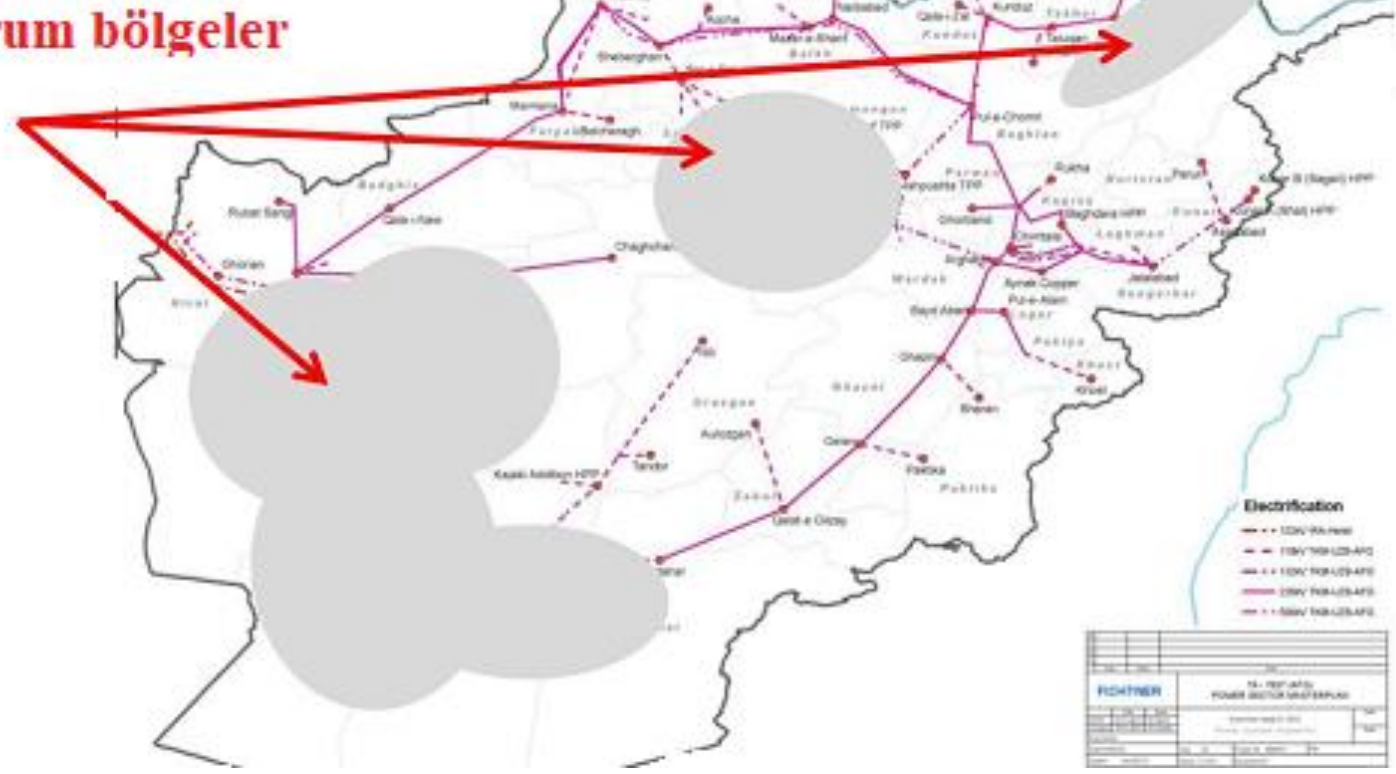

Şekil 3.4. Afganistan'da 20 yıldır şebekeden mahrum bölgeler (Nasrati, 2015; Ludin ve ark., 2017a'dan uyarlanmıştır). 


\section{Afganistan'ın Geleceği için Yenilenebilir Enerji Potansiyeli}

Afganistan'ın geleceği için yenilenebilir enerji potansiyelinin önemi üzerine yapılan önemli çalışmalardan biri de Fahmi ve Upham (2017)'ın çalışmasıdır. Bu çalışmada Afganistan'daki hidro, güneş, jeotermal, rüzgar ve biyo-kütle gibi doğa dostu yenilenebilir enerji kaynaklar1, potansiyelleri ve kullanım durumları irdelenmiştir. Bu ülkenin güneş, rüzgar ve hidrolik enerji potansiyeli yüksektir. $\mathrm{Bu}$ kaynaklardan hem büyük hem de küçük ölçekte yararlanılması için yeterince iyi potansiyel bulunmaktadır. Örneğin, yerli elektriğin çoğu hidroelektrik santrallerinden üretilmektedir. Ancak, ülkede fotovoltaik güneş ve rüzgar santrallerinden enerji üretim konusunda küçük ölçekte uygulamalar bulunmaktadır. Afganistan'da biyokütle; genellikle tarımsal atık şeklinde olup, daha çok yemek pişirmek ve 1sınmak için doğrudan kullanılmaktadır. Ayrıca, bu kaynaktan elektrik üretmek için de küçük miktarlarda ve kişisel girişimler bulunmaktadır. Afganistan'da jeotermal önemli olmasına rağmen, bu kaynakla ilgili şu ana kadar geniş bir şekilde araştırma yapılmamıştır (Anonim, 2018b). Afganistan'ın Enerji ve Su Bakanlığı'na göre, Afganistan yıllık 67.000 MW rüzgar enerji potansiyeline, 220.000 MW güneş enerji potansiyeline, 4.000 MW biyokütle enerji potansiyeline ve 23.000 MW'in üzerinde hidrolik potansiyeline sahip olan bir ülkedir (Anonim, 2014b; Sherzai, 2017; Ahmadzai ve MacKinna, 2018). Bu ülkenin 19 ilinde, önümüzdeki birkaç yıl içinde yenilenebilir enerji kaynaklarından özellikle güneş, hidro, biyokütle ve rüzgârdan elektrik üretilmesi için toplam $100 \mathrm{MW}$ kapasiteye sahip olacak 30 projenin hayata geçirilmesi öngörülmektedir. Bu projelerin toplam maliyetinin yaklaşık 326 milyon ABD Doları olduğu tahmin edilmektedir ve ülkedeki 1.000 .000 kişiye elektrik sağlayacağı öngörülmektedir (Anonim, 2016). Şekil 4.1'de her bir enerji türünden elektrik üretim kapasite miktarları görülmektedir ve Şekil 4.2'de birkaç yıl içinde her enerji türü için yapılacak yatırımların yüzdesi görülmektedir. Ayrıca, Çizelge 4.1'de 2032 yılına kadar yenilenebilir enerji kaynaklarından elektrik üretiminin öngörülen kapasitesi verilmiştir.

Enerji Kaynaklarma Göre Elektrik Üretim Kapasiteleri (MW)

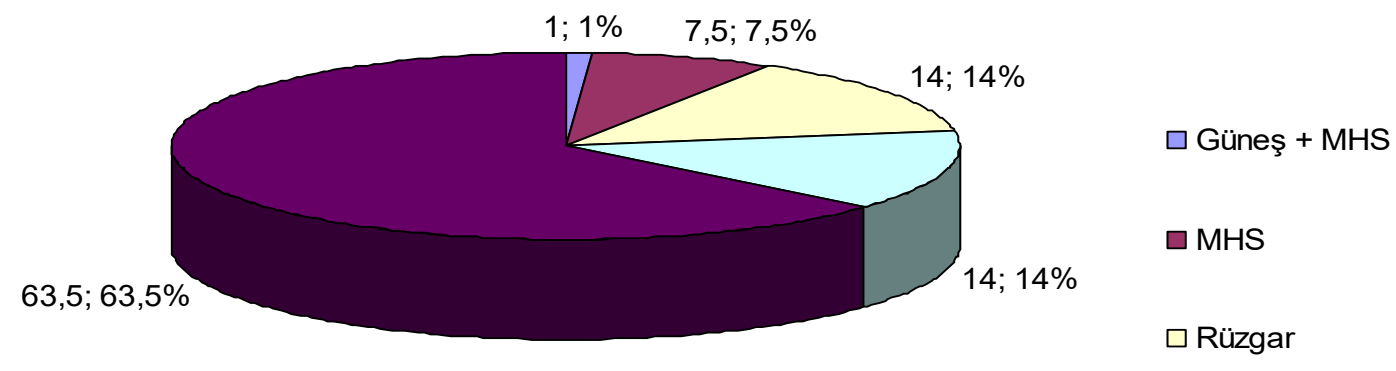

$\square$ Biyo Kütle

Güneş

Şekil 4.1. Önümüzdeki birkaç yıl içinde farklı enerji kaynağı türlerinden elektrik enerjisi üretim kapasitesi (Anonim, 2016'den uyarlanmıştır). 


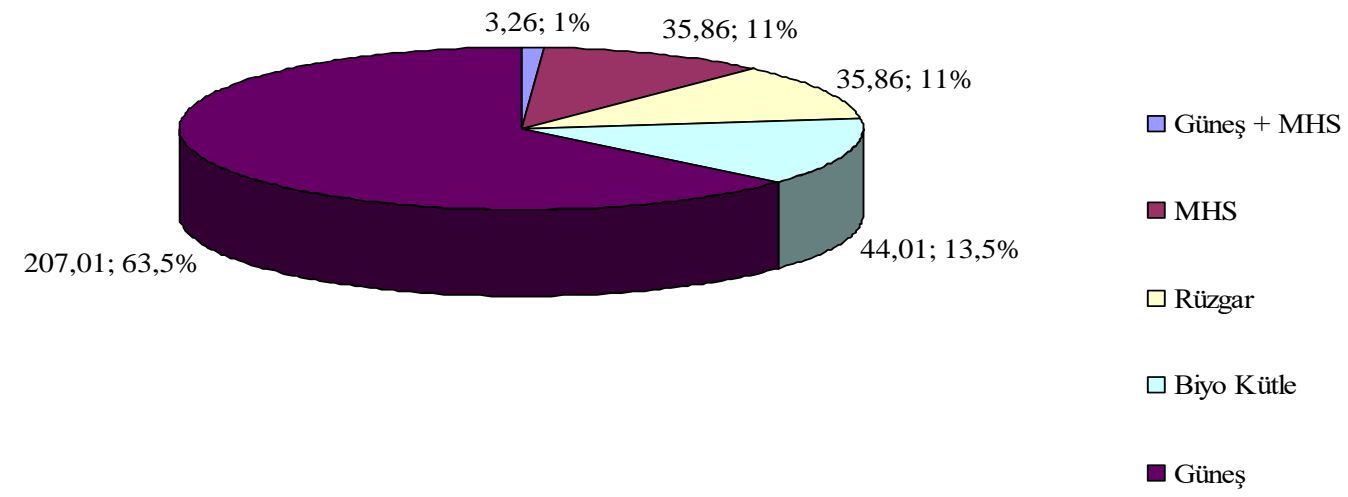

Şekil 4.2. Önümüzdeki birkaç yıl içinde her enerji türünden elektrik üretim için yatırım dağılımı ve yüzdeleri (Anonim, 2016'den uyarlanmıştır).

Çizelge 4.1. 2032 yılına kadar yenilenebilir enerji kaynaklarından üretilen elektrik kapasitesi (Anonim, 2017b'den uyarlanmıştır)

\begin{tabular}{|c|r|l|r|r|}
\hline \multirow{4}{*}{ Enerji Türü } & \multirow{2}{*}{ No: } & \multicolumn{1}{|c|}{ Teknoloji } & $\begin{array}{r}\text { Kapasite } \\
\text { (MW) }\end{array}$ & \multicolumn{1}{c|}{$\%$} \\
\hline \multirow{5}{*}{ Güneş } & 1 & Güneş Enerjisi Parkları & 590 & 11,79 \\
\cline { 2 - 5 } & 2 & Güneş Enerjisinden Bağımsız Güç Üreticileri & 210 & 4,20 \\
\cline { 2 - 5 } & 3 & Yoğunlaştırıcı Güneş Enerjisi & 110 & 2,20 \\
\cline { 2 - 5 } & 4 & Yüzer Fotovoltaik & 10,50 & 0,21 \\
\cline { 2 - 5 } & 5 & Konsantre Fotovoltaik & 6 & 0,12 \\
\cline { 2 - 5 } & 6 & Çatı Üstü ile Şebeke - toplantı / montaj & 420 & 8,40 \\
\cline { 2 - 5 } & 7 & PV Ev Sistemleri, İletişim Kuleleri ve Diğerleri & 75 & 1,50 \\
\cline { 2 - 5 } & 8 & Güneş Enerjili Pompa Sistemleri & 51 & 1,02 \\
\cline { 2 - 5 } & 9 & Vakum tüp ve Düz Plaka & 60,6 & 1,21 \\
\hline Rüzgar & 10 & Rüzgardan Bağımsı Güç Üreticileri & 600 & 11,99 \\
\hline Büyük Hidrolik & 11 & Büyük Hidrolik & 2.000 & 39,98 \\
\hline Biyokütle & 12 & Tarımsal Atıklardan Elektrik Üretimi & 30 & 0,60 \\
\hline \multirow{2}{*}{ Biyogaz } & 13 & Organik ve Tarımsal Atık & 4,1 & 0,04 \\
\cline { 2 - 5 } & 14 & Termal Enerji & 56 & 1,12 \\
\hline Atık & 15 & Belediye Katı Atık & 55 & 1,10 \\
\hline Jeotermal & 16 & Isı Pompası Uygulamaları ve Jeotermal Enerji & 300 & 6,00 \\
\hline Hibrid & 17 & Dizel + Rüzgar / Güneş / Mini Hidro & 420 & 8,40 \\
\hline MHS \& KHS & 18 & Mikro Hidro Santral + Küçük Hidro Santral & 0,05 \\
\hline Aşçı sobaları & 19 & Termal Enerji & $5.002,8$ & 100,00 \\
\hline & & & Toplam & \\
\hline
\end{tabular}




\subsection{Afganistan'daki Güneş Enerji Potansiyeli}

Afganistan fotovoltaik güneş pillerinin (PV) geliştirilmesi için önemli coğrafi koşullara sahiptir. Afganistan'ın güneş enerjisi potansiyeli; ABD Ulusal Yenilenebilir Enerji Laboratuvarı (NREL) tarafından 2014 yılında analiz edilmiştir (Anonim, 2019b). Yapılan bu analiz çalışmalarında; Afganistan yıllık 300 güneşlenme gününe ve ortalama günlük 5,5 $\mathrm{kWh} / \mathrm{m}^{2}$ 'nin üzerinde güneş enerjisi potansiyeline sahip olduğu belirtilmektedir. Öte yandan, Afganistan'ın Enerji ve Su Bakanlığı'na göre, bu ülke günde ortalama $6,5 \mathrm{kWh} / \mathrm{m}^{2}$ ve 12 saat/gün küresel yatay 1șınım potansiyeline sahip olduğu ve toplam yaklaşık 220.000 MW'l1k güneş enerji potansiyeline sahip olduğu belirtilmiştir. Yapılan bu çalışmalarda; genellikle, Afganistan'nın güney kısmında Kandahar ve Helmand gibi illerde ve batı kısmında Farah, Herat ve Nimruz gibi illerde önemli güneş enerjisi sahaları olduğu ifade edilmektedir. Halbuki, kuzey illeri içinde günlük ortalama $4,5 \mathrm{kWh} / \mathrm{m}^{2}$ güneş 1 şınıma sahip olduğuna dair çalışmalar bulunmaktadır (Elliott, 2016; Ludin ve ark., 2017a; Anonim, 2017c). Şekil 4.3'te Afganistan'ın güneş enerjisi atlası gösterilmektedir.

Çizelge 4.2'de gösterildiği gibi, $100 \mathrm{~kW}$ 'lı kapasiteye sahip olan ilk fotovoltaik sistemi şebekeden bağımsız olarak 2010 yılında Gardez ilinin Syed Karam ilçesinde kurulmuştur (Anonim 2017a). Bu sistem $250 \mathrm{~kW}$ yedekleme ünitesine sahip olan bir dizel jeneratörü ile birleştirilmiştir. Güneş enerjisinden yararlanan bu sistem neredeyse 600 evin elektrik ihtiyacını karşılamaktadır.

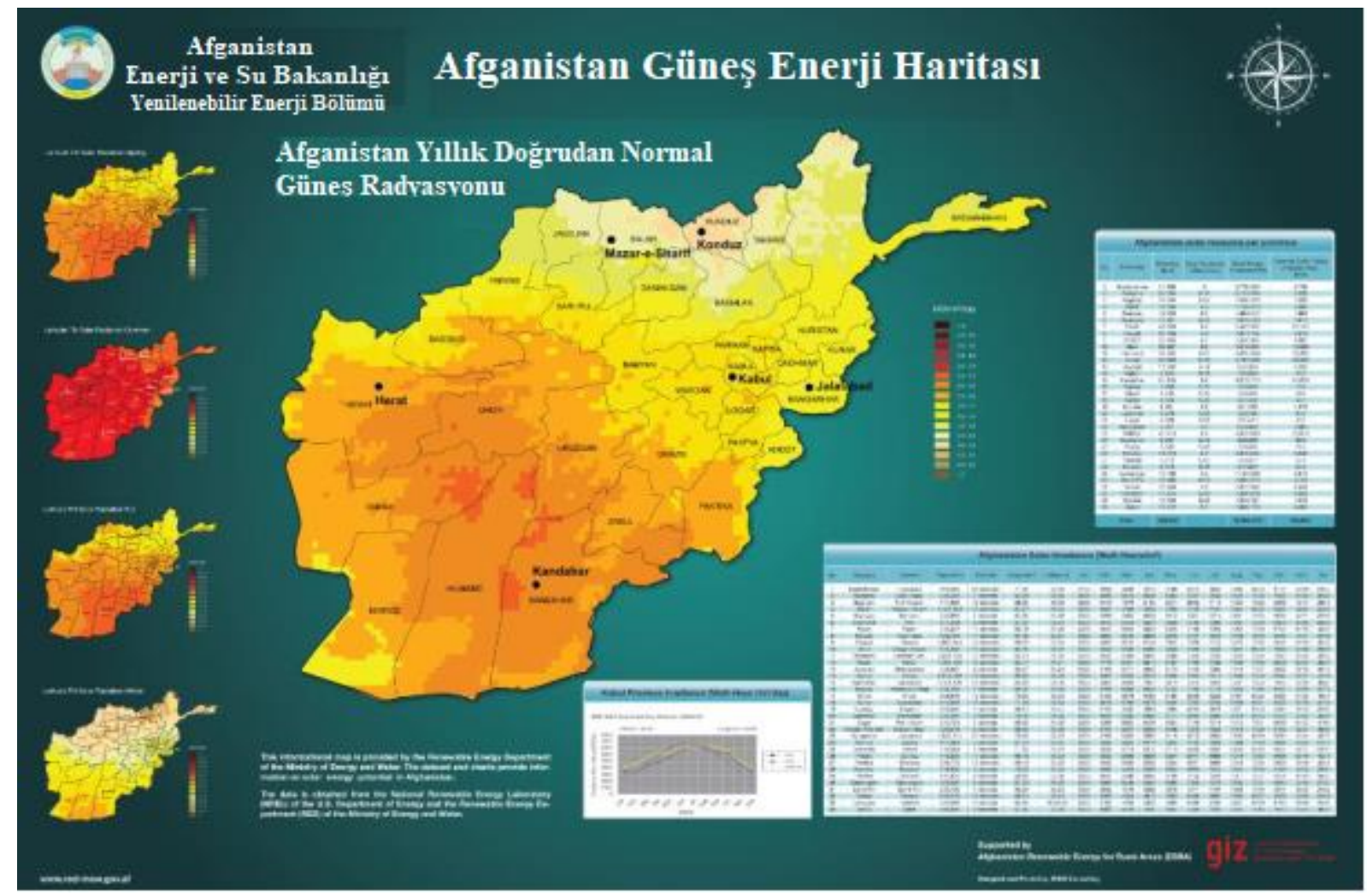

Şekil 4.3. Afganistan'ın güneş radyasyon potansiyelini gösteren güneş enerji atlası (Anonim, 2016'den uyarlanmıştır)

2013 yılında güneş enerjisinden elektrik üretmek için fotovoltaik panelleri ikinci sistem olarak inşa edilmiştir. Üçüncüsü ise 2014 yılında 1 MW'lık kapasite ile kullanılmaya başlanmış ve $2.500 \mathrm{ev}$, iş yerleri ve devlet daireleri için elektrik sağlamıştır (Anonim, 2017b). Afganistan 
Enerji ve Su Bakanlığı'nın verilerine göre, 2016 yılına kadar toplam 13 MW'lık kapasite fotovoltaik panellerini kurarak güneş enerjisinden elektrik üretilmeye başlanmıştır. Ayrıca, Afganistan'ın Enerji ve Su Bakanlığ tarafindan 1,8 MW'lık kapasite ile PV panellerinden yakın zamanda elektrik üretileceği de belirtilmiştir (Anonim, 2017b). Bu çalışmalarda; Enerji ve Su Bakanlığı'nın Yenilenebilir Enerji Şubesi’nin koordinatörlüğünde, 2017 yılında bir kaç büyük güneş enerjisi projesinden de elektrik üretmek için çalışmaların devam ettiği belirtilmektedir. Bu projeler toplam $112 \mathrm{MW}$ 'lık kapasiteye sahip olup, şebeke bağlı sistem olarak inşa edilmektedir. Bu çalışmalarda, $2 \mathrm{MW}$ güneş ve $10 \mathrm{MW}$ rüzgar olmak üzere toplam $12 \mathrm{MW}$ kapasiteye sahip olan diğer iki proje şebeke bağlı olarak hibrit şeklinde (güneş + rüzgar) inşa aşamasında olduğu belirtilmektedir. Ayrıca şebekede bağlı olarak hibrit şeklinde (güneş + hidro) toplam $100 \mathrm{MW}$ 'lık kapasite de öngörülmektedir. Üstelik toplam $400 \mathrm{~kW}$ 'lık kapasite fotovoltaik güneş panellerinden şebekeden bağımsız olarak projelendiği de ifade edilmiştir (Anonim, 2016). Çizelge 4.3'te güneş enerji teknolojilerine göre proje başına elektrik üretim kapasitesi ve Şekil 4.4'te 2032 yılına kadar kullanılacak güneş enerji teknolojileri yüzdesi gösterilmektedir (Anonim, 2016; Anonim 2017a). Çizelge 4.3'te gösterildiği gibi, 2032 yılına kadar farklı tür güneş enerji teknolojilerin kullanarak 1.500 MW'lık kapasite üzerinde güneşten enerji üretilmesi öngörülmektedir. Bu projeler $900 \mathrm{MW}$ şebekede bağlı sistem ve 600 MW'ta şebekeden bağımsız sistemden oluşmaktadır (Anonim, 2017b).

Çizelge 4.2. Afganistan'da 2010 yılından 2014 yılına kadar fotovoltaik güneş panellerinden üretilen elektrik (Anonim, 2017b'den uyarlanmıştır)

\begin{tabular}{|c|c|c|c|c|c|c|c|}
\hline No & Yil & Il & Tür & Sistem & Binalar & $\begin{array}{c}\text { Kapasite } \\
(\mathrm{kW})\end{array}$ & $\%$ \\
\hline 1 & 2010 & Gardez & Güneş & Şebekeden Bağımsız & 600 & 100 & 7,44 \\
\hline 2 & 2013 & Takhar & Güneş & Şebekeden Bağımsız & 923 & 244 & 18,15 \\
\hline 3 & 2014 & Bamyan & Güneş & Şebekeden Bağımsız & 2.500 & 1.000 & 74,40 \\
\hline \multicolumn{6}{|c|}{ TOPLAM } & 1.344 & 100,00 \\
\hline
\end{tabular}

Çizelge 4.3. 2032 yılına kadar güneş sistemlerinden üretilmekte olan toplam elektrik kapasitesi (Anonim, 2017b'den uyarlanmıştır)

\begin{tabular}{|c|l|r|r|}
\hline No & \multicolumn{1}{|c|}{ Güneş enerji teknoloji türü } & $\begin{array}{r}\text { Projelendirilen kapasite } \\
(\mathrm{kW})\end{array}$ & \multicolumn{1}{c|}{} \\
\hline 1 & Güneş enerjisi park sistemleri & 590,0 & 38,5 \\
\hline 2 & Solar bağımsız güç üretim sistemleri & 210,0 & 13,7 \\
\hline 3 & Yoğunlaştırıcı güneş enerjisi sistemi & 110,0 & 7,2 \\
\hline 4 & Yüzen fotovoltaik sistemi & 10,5 & 0,7 \\
\hline 5 & Yoğunlaştırıcı fotovoltaik sistemi & 6,0 & 0,4 \\
\hline 6 & Net - çatı üstü sistem ile toplantı & 420,0 & 27,4 \\
\hline 7 & Ev, telekom kuleleri ve diğerleri fotovoltaik sistemleri & 75,0 & 4,9 \\
\hline 8 & Güneş pompalama sistemi & 51,0 & 3,3 \\
\hline 9 & Düz plaka ve boşaltma tüpü sistemi & 60,6 & 4,0 \\
\hline & Toplam Kapasite & $1.533,1$ & 100,0 \\
\hline
\end{tabular}




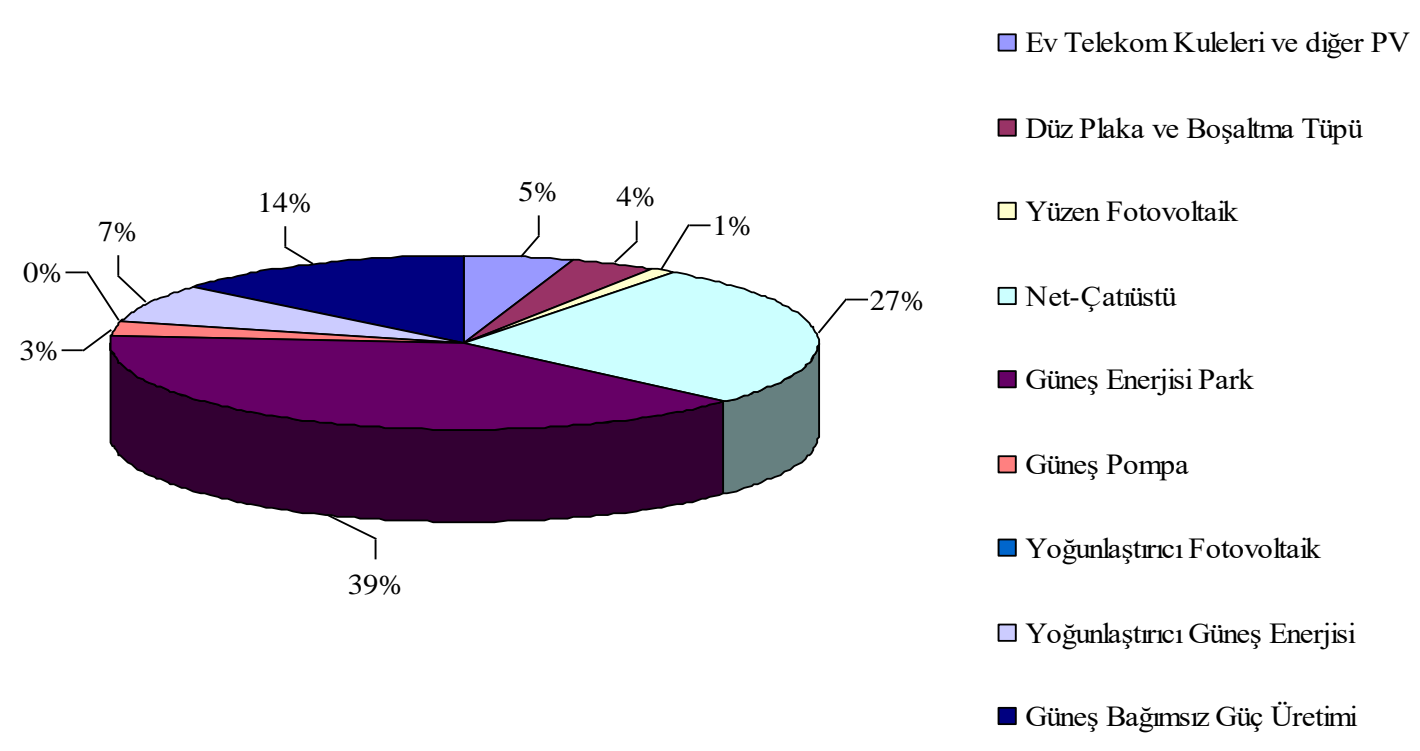

Şekil 4.4. 2032 yılına kadar teknolojilerin kullanım yüzdesi (Anonim, 2017b'den uyarlanmıştır).

\subsection{Afganistan'daki Rüzgar Enerjisi Potansiyeli}

Afganistan çok önemli rüzgar enerjisi potansiyeline sahiptir. Bu ülkedeki rüzgar enerji potansiyeli, ABD Ulusal Yenilenebilir Enerji Laboratuvarı (UYEL) tarafindan 2014 yılında analiz edilmiştir (Anonim, 2019b). Bu çalışmalarda Afganistan, toplam $652.864 \mathrm{~km}^{2}$ sahip olduğu alandan $31.600 \mathrm{~km}^{2} \quad(\% 4,84)$ alanı ile büyük ölçekli ve oldukça verimli rüzgar santrallerinden yararlanılabileceği ifade edilmektedir. $\mathrm{Bu}$ alanın potansiyelinin toplam 158.000 MW'llk rüzgar enerjisi $\left(5 \mathrm{MW} / \mathrm{km}^{2}\right)$ için yeterli olduğu tahmin edilmiştir (Anonim 2019a; Anonim, 2019b). Ancak Afganistan'ın Enerji ve Su Bakanlığı'na göre, bu ülke zayıf altyap1 nedeniyle sadece 66.726 MW'lık $(\% 42,23)$ rüzgar enerjisi uygulanabilir kurulum kapasitesine sahiptir (Elliott, 2016; Ludin ve ark., 2017a). Ulusal Yenilenebilir Enerji Laboratuvarı sonuçlarına göre, ülkedeki uygulanabilir rüzgar potansiyeli çoğunlukla aşağıdaki bölgelerde bulunmaktadır (Elliott, 2016; Fahmi ve Upham, 2017; Ludin ve ark, 2017a):

- Batı bölgelerinde; Herat, Farah ve Nimroz

- Kuzey doğu bölgelerinde; Takhar ve Balkh

- Doğu bölgelerinde koridor rüzgar alanları; Tirgari, Sarobi ve Jabalsar

- Ülkenin orta/güney kısımlarında; Gadamsar, Golestan, Gorzanak Qalat and Walakhor

- Ülkenin kuzey ve doğusunda; genellikle sırt tepelerinde ve yüksek dağ zirvelerinde bulunmaktadir.

Çizelge 4.4 iyi ile mükemmel (sınıf 4+) arasındaki güç yoğunluklarını 400-600 W/m² ve hızın $6,8-7,7 \mathrm{~m} / \mathrm{s}$ olduğunu göstermektedir ve bu değerlerin uygulamalar için uygun olduğu vurgulanmakla birlikte Afganistan'daki arazilerin yaklaşı \% 12'sinin sınıf 3 veya daha iyi bir rüzgar kaynağına sahip olduğu da belirtilmektedir (Elliott 2016). Afganistan'da modern anlamda herhangi bir şebeke ölçekli rüzgar sistemine sahip olunmamasına rağmen, 2015 yılına kadar toplam $230 \mathrm{~kW}$ 'lık kapasitede rüzgar türbin santralleri kurulabilmiştir. Elliott 
(2016) tarafından yapılan çalışmada 2008 yılına kadar 10 adet rüzgar türbini ile toplam 100 kW'lık bir kapasiteye sahip olan rüzgar çiftliği Pençşir illinde devreye alınacağı da belirtilmektedir. Yenilenebilir Enerji Şubesine göre (Anonim, 2017b); 1,7 MW'lık kapasite güneşten ve $300 \mathrm{~kW}$ 'lık rüzgardan olmak üzere toplam $2 \mathrm{MW}$ hibrit santrallerin Afganistan'ın Herat ilinde 2017 yılında yapım aşamasında olduğu belirtilmiştir. Bu çalışmalarda da vurgulandığı gibi, birkaç yıl içinde yenilenebilir enerji kaynaklarından 100 MW kapasitede enerji üretilmesi öngörülmektedir. Ancak, bu kapasitenin $14 \mathrm{MW}^{\prime} 1$ Herat ilinde rüzgar enerjisinden üretileceği ve 36 milyon ABD doları maliyeti olacağı tahmin edilmektedir (Anonim, 2016). Afganistan'ın Yenilenebilir Enerji Yol Haritasına göre, 2032 yılına kadar rüzgar enerjisinden $600 \mathrm{MW}$ 'lık bir elektrik kapasitesi üretileceği öngörülmektedir (Anonim, 2017b). Şekil 4.5'te Afganistan'1n rüzgar enerjisi atlas1 görülmektedir (Nasrati, 2015).

Çizelge 4.4. Afganistan'ın 50 m yükseklikteki rüzgar enerji potansiyeli (Nasrati, 2015; Elliott, 2016'den uyarlanmıştır)

\begin{tabular}{|c|c|c|c|c|c|c|c|}
\hline \multicolumn{2}{|c|}{$\begin{array}{c}\text { Rüzgar } \\
\text { Sinıfı }\end{array}$} & $\begin{array}{l}\text { Rüzgar Gücü } \\
\left(\mathrm{W} / \mathrm{m}^{2}-50 \mathrm{~m}\right)\end{array}$ & $\begin{array}{l}\text { Rüzgar Hizı } \\
(\mathrm{m} / \mathrm{s} 50 \mathrm{~m})\end{array}$ & $\begin{array}{c}\text { Toplam } \\
\text { Alan } \\
\left(\mathrm{km}^{2}\right)\end{array}$ & $\begin{array}{c}\text { Rüzgarlı } \\
\text { Bölge } \\
(\%)\end{array}$ & $\begin{array}{c}\text { Toplam } \\
\text { Potansiyel } \\
\text { (W) }\end{array}$ & $\%$ \\
\hline 1 & Zayif & $0-200$ & $0-5,4$ & & & & \\
\hline 2 & Düsük & $200-300$ & $5,4-6,1$ & & & & \\
\hline 3 & Orta & $300-400$ & $6,1-6,8$ & & & & \\
\hline 4 & İyi & $400-500$ & $6,8-7,3$ & 15.193 & 2.40 & 75.970 & 48,07 \\
\hline 5 & Çok iyi & $500-600$ & 7,3-7,7 & 6.633 & 1.00 & 33.160 & 20,98 \\
\hline 6 & Harika & $600-800$ & $7,7-8,5$ & 6.615 & 1.00 & 33.100 & 20,95 \\
\hline 7 & Mükemmel & $800<$ & $8,5<$ & 3.169 & 0.50 & 15.800 & 10,00 \\
\hline \multicolumn{4}{|c|}{ Toplam } & 31.611 & 4.90 & 158.030 & 100,00 \\
\hline
\end{tabular}
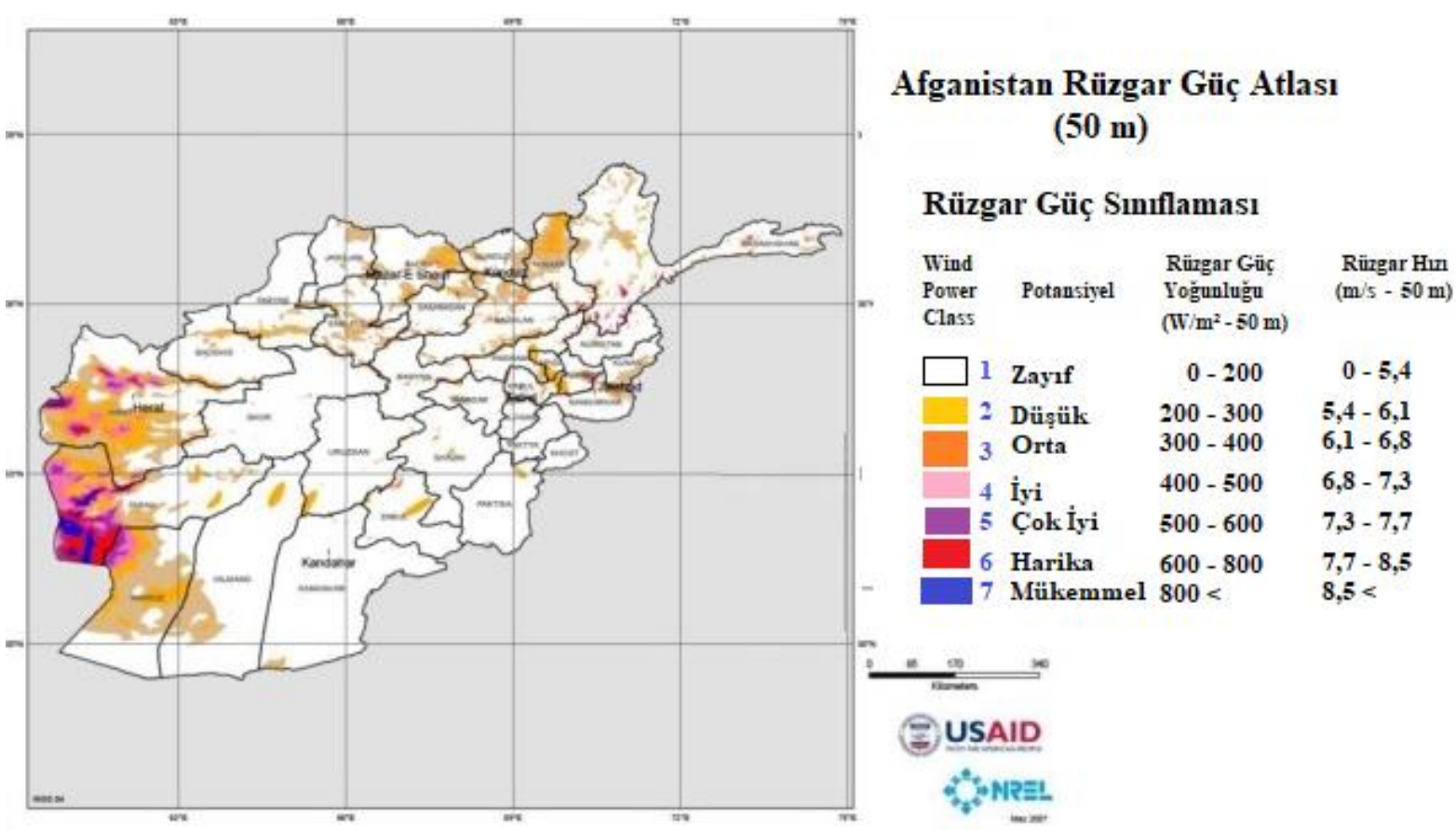

Şekil 4.5. Afganistan'ın 50 m'deki rüzgar potansiyelini veren rüzgar enerji atlası (Nasrati, 2015; Elliott, 2016'den uyarlanmıştır) 


\subsection{Afganistan'daki Hidrolik Enerji Potansiyeli}

Afganistan genel olarak, dağlık arazilere ve geniş nehir sistemlerine sahiptir. Afganistan Enerji ve Su Bakanlığı raporlarına göre, ülkede 23.000 MW'tan daha fazla hidroelektrik enerji potansiyeli mevcuttur (Anonim 2018b). Sherzai (2017) tarafından yapılan çalışmada; mevcut potansiyelin yaklaşık 20.000 MW'lık (\%87) kısmının ülkenin kuzey ve doğusunda bulunan Amu, Panj ve Kokcha gibi çok büyük nehirlerde ve 1.900 MW üzerindeki kısmının $(\% 8,3)$ ise Kabil bölgesinin doğu kısmında yer aldığı belirtilmiştir. Aynı çalışmada ülkenin Kuzeyinde Balkh ve Jowzijan gibi illerde yaklaşık 800 MW'lı hidroelektrik enerji potansiyeli $(\% 3,5)$ bulunduğu vurgulanmıştır. Potansiyelin \%2,2'lik kısmına karş1lık gelen yaklaşık 500 MW'lık kısmı ise ülkenin batı orta kısmında yer almaktadır (Anoymous, 2018b; Sherzai, 2017). Afganistan'ın toplam dokuz ilinde, 600 MW üzerinde elektrik potansiyeli yaklaşık 125 Mikro/Mini Hidroelektrik Santral (MHS) olarak öne çıkmaktadır (Musleh, 2016). Çizelge 4.5'ten de görüleceği gibi, 2016 yılında Salma barajından devreye alınan 42 MW'lık kapasite de dahil olmak üzere, yaklaşık 296 MW ilave Büyük Hidroelektrik Santral'den ülke çapında elektrik üretilmektedir (Anonim, 2018b). Çizelge 4.6'da Afganistan'daki toplam hidroelektrik potansiyelinin bölgelere göre dağılımı göstermektedir (Ludin ve ark., 2017a). Bu dağılıma göre, Afganistan'daki mevcut kurulan hidroelektrik santralleri genel olarak $300 \mathrm{~kW}$ ile 100 MW'lık arası bir kapasiteye sahiptir. Halbuki, ülkedeki mevcut kurulan mikro santrallerin kapasitenin $100 \mathrm{~kW}$ 'tan daha az olduğu belirtilmektedir (Ershad, 2017). Enerji ve Su Bakanlığı'nın verilerine göre, ülkedeki hidrolik kaynaklarından toplam 296 MW'lık civarında elektrik kapasitesi bulunmaktadır. Bu değerin çoğu Kabil bölgesinde; Naghlu 100 MW'lık, Mahiper 66 MW'lık, Surobi 22 MW'llk kapasiteye ve Herat ilinde Selma 42 MW'lık güce sahip olmak üzere, Çizelge 4.5 'te gösterildiği gibi ülkenin farklı bölgelerinde enerji üretimine katkı sağlamaktadır.

Birleşmiş Milletler Kalkınma Program'ına (BMKP) göre, ülke çapında son 10 yıl içinde yaklaş1k 240 adet mikro hidroelektrik santralleri inşa edilmiştir (Anonim, 2017b). Afganistan'ın Kırsal Rehabilitasyon ve Kalkınma Bakanlığı (KRKB) ve Enerji ve Su Bakanlığı tarafından gelen raporlara (Anonim, 2017b) göre, yaklaşık 30 MW'lık kurulan ve 6 MW'tan daha fazlası yapım aşamasında olmak üzere ülke çapında mikro/mini hidroelektrik santrallerinden elektrik üretilmektedir (Anonim, 2017c). 
Çizelge 4.5. Afganistan'daki mevcut kurulan hidroelektrik santrallerin bölgelere dağılımı (Anonim, 2018b; Ershad, 2017'den uyarlanmıştır)

\begin{tabular}{|c|c|c|c|c|c|}
\hline No & Ad 1 & Bölge & Kapasite (MW) & $\%$ & $\begin{array}{c}\text { İşletmeye alma / } \\
\text { rehabilitasyon tarihi }\end{array}$ \\
\hline 1 & Naghlu & Kabul & 100 & 33,82 & $1967 / 2013$ \\
\hline 2 & Mahiper & Kabul & 66 & 22,32 & $1957 /$ \\
\hline 3 & Surobi & Kabul & 22 & 7,44 & $1967 /$ \\
\hline 4 & Darunta & Kabul & 11,5 & 3,89 & $1964 / 2012$ \\
\hline 5 & Kajaki (I \& III) & Helmand & 33 & 11,16 & $1975 /$ \\
\hline 6 & Herat & Selma dam & 42 & 14,20 & /2016 \\
\hline 7 & Polikhumri & Polikhumri II dam & 8,79 & 2,97 & $(1962) /(2013-2015)$ \\
\hline 8 & Polikhumri & Polikhumri dam & 4,12 & 1,39 & $(1950) /(2013-2015)$ \\
\hline 9 & Jabul Ser. & Salang & 2,5 & 0,85 & $1920 /$ \\
\hline 10 & Grishk & Helmand & 2,4 & 0,81 & $1957 /$ \\
\hline 11 & Charikar & Ghorband & 2,4 & 0,81 & 1973/ \\
\hline 12 & Assassab. & Kunar & 0.7 & 0,24 & 1983/ \\
\hline 13 & Ghorband & Ghorband & 0.3 & 0,10 & $1975 /$ \\
\hline \multicolumn{3}{|c|}{ Toplam } & 295,71 & 100,00 & \\
\hline
\end{tabular}

Çizelge 4.6. Afganistan'daki hidrolik potansiyelin bölgelere göre dağılım potansiyeli (Ludin ve ark, 2017a'den uyarlanmıştır)

\begin{tabular}{|c|c|c|c|c|}
\hline $\mathrm{No}$ & Bölge & Büyük Nehirler & Kapasite (MW) & Kapasite (\%) \\
\hline 1 & \multirow{4}{*}{ Kabil } & Kabul & 408 & 1,75 \\
\hline 2 & & Panjshir & 400 & 1,72 \\
\hline 3 & & Laghman & 44 & 0,19 \\
\hline 4 & & Kunar & 1089 & 4,67 \\
\hline 5 & \multirow{4}{*}{ Panj-Amu } & Panj & 9050 & 38,82 \\
\hline 6 & & Amu & 9110 & 39,08 \\
\hline 7 & & Kokcha & 1927 & 8,27 \\
\hline 8 & & Kunduz & 50 & 0,21 \\
\hline 9 & \multirow{2}{*}{ Kuzey } & Jawzjan & 460 & 1,97 \\
\hline 10 & & Balkh & 300 & 1,29 \\
\hline 11 & \multirow{2}{*}{ Harirod-Murghab } & Harirod & 102 & 0,44 \\
\hline 12 & & Murghab & 100 & 0,43 \\
\hline 13 & \multirow{2}{*}{ Helmand } & Helmand & 190 & 0,82 \\
\hline 14 & & farah Rod & 80 & 0,34 \\
\hline \multicolumn{3}{|c|}{ Toplam } & 23.310 & 100,00 \\
\hline
\end{tabular}


$\mathrm{Bu}$ çalışmalarda; önümüzdeki birkaç y1l içinde, toplam $100 \mathrm{MW}$ 'lık yenilenebilir enerji kaynaklarından elektrik üretilmesi çalışmalarının devam etmekte olduğu belirtilmiştir. Ayrıca; 7,5 MW civarında mikro/mini hidroelektrik santrallerden de oldukça ekonomik elektrik üretilebileceği ifade edilmekte olup bu tür projelerin 36 milyon dolar maliyeti olacağı tahmin edilmektedir (Anonim, 2016). Afganistan'daki su kaynaklarından, 2032 yılına kadar büyük hidroelektrik santrallerden $2.000 \mathrm{MW}$ 'lık, hibrit şeklinde mikro hidroelektrik + küçük hidroelektrik santrallerinden $420 \mathrm{MW}$ ve dizel + rüzgar/güneş/mikro hidrolik santrallerinden 300 MW'lık ek projelerde bulunmaktadır (Anonim, 2017b).

\subsection{Afganistan'daki Biyokütle Potansiyeli}

Afganistan'da biyokütle kaynağı olarak kullanılan hayvan gübreleri, mahsul kalıntıları ve belediye katı atıkları gibi kaynaklar çok yüksek seviyede bulunmaktadır. Afganistan'daki mahsul kalıntıları, hayvansal atıklar çoğunlukla kırsal alanlarda toplanmaktadır. Bu kaynaklar doğrudan evlerde 1sıtma ve pişirme için kullanılmaktadır. Öte yandan, belediye atıkları çoğunlukla kentsel alanlarda toplanmaktadır (Anonim, 2013). Enerji ve Su Bakanlı̆̆ı'nın raporuna göre, ülke $4.000 \mathrm{MW}$ biyokütle enerji potansiyeline sahiptir. Bu çalışmaya göre, yıllık 39.187.000 ton hayvan gübresi, 6.490.000 ton mahsul kalıntıları ve 3.720.000 ton belediye katı atıkları oluşmaktadır. Bu değerlerin sırasıyla 7.367.000 MWh, 27.083.000 MWh ve 819.000 MWh elektrik üretmeye eşdeğer olduğu belirtilmektedir (Musleh, 2016). Ershad (2017) tarafından yapılan çalışmada, Afganistan'da biyokütlenin sadece kırsal alanlarda yaşayan nüfus için değil aynı zamanda kentsel alanlar için de yakıt kaynağı olarak çok önemli rol oynadığı ifade edilmektedir. Afgan halkı genel olarak enerji ihtiyacının \%85'ten fazlasını geleneksel biyokütle ile karşılamaktadır ve bunlar çoğunlukla odun ve gübreden oluşmaktadır. Ülkedeki diğer biyokütle kaynakları; insanların/hayvanların ve belediyelerin atıklarından oluşmaktadır (Musleh, 2016). Afganistan nüfusunun yaklaşık \% 80'i katı biyokütle kaynaklarını yemek pişirme amaciyla kullanırken \% 97,4'ü ise 1sınma amacıyla kullanmaktadır (Ershad, 2017). Çizelge 4.7'de katı yakıtların pişirme ve 1sıtma amacıyla farklı yaşam alanları tarafından kullanım yüzdesini göstermektedir. Örneğin, biyogaz birincil olarak kentsel bölgelerin nüfusu tarafından yemek pişirmek için kullanılırken, odun birincil olarak ve kömür ikincil olarak kentsel bölgeler tarafından ısıtma amacıyla kullanılmaktadır. Ancak, odun, hayvan gübresi ve çalılar çoğunlukla kırsal bölgelerde yemek pişirmek ve ısınmak için yakıt olarak kullanmaktadır. Diğer taraftan, hayvan atıkları Kuchi bölgelerinde sadece yemek pişirmek için değil aynı zamanda evleri 1sıtmak için en önemli yakıt olarak kullanılmaktadır (Snallen, 2004; Musleh 2016; Ershad 2017).

Çizelge 4.7. Afganistan'daki farklı yaşam bölgelerin nüfusunun tarafından kullanılan katı atık yüzdesi (Alamyar, 2014; Ershad, 2017'den uyarlanmıştır)

\begin{tabular}{|l|c|c|}
\hline \multicolumn{1}{|c|}{ Farklı yaşam bölgeleri } & Pişirme için (\%) & Isıtma için (\%) \\
\hline Kentsal bölge & 32,5 & 99,1 \\
\hline Kursal bölge & 93,4 & 92,3 \\
\hline Göçebe bölge & 99,8 & 100 \\
\hline Ulusal olarak & 79,9 & 97,4 \\
\hline
\end{tabular}

Son on yıl içinde, Afganistan'da Birleşmiş Milletler Kalkınma Programı tarafından 44 biyogaz tesisleri kurulduğu ve bu tesislerin çok başarılı şekilde çalıştığı ifade edilmektedir (Anonim, 2017c). Ülke genelinde 350 küçük biyogaz sistemi inşa edildiği tahmin edilmektedir (Musleh, 2016). Şekil 4.6'da Afganistan'daki sığır gübresi kullanarak yerli biyogaz tesisi kurulumu için uygun bölgeler, Şekil 4.7'de mahsul kalıntıları veya bitki atıkları 
ve Şekil 4.8'de belediye katı atıklarının olduğu bölgeleri göstermektedir (Milbrandt ve Overend, 2011). Ayrica, Afganistan'da 2032 yılına kadar toplam 88 MW'lik biyokütle kaynaklarından elektrik üretileceği öngörülmektedir. Bunların 30 MW'1 tarımsal atıklardan, 56 MW' 1 belediye katı atıklarından ve diğeri de organik ve tarımsal atıklardan üretilmesi olarak bildirilmektedir (Anonim, 2017b).

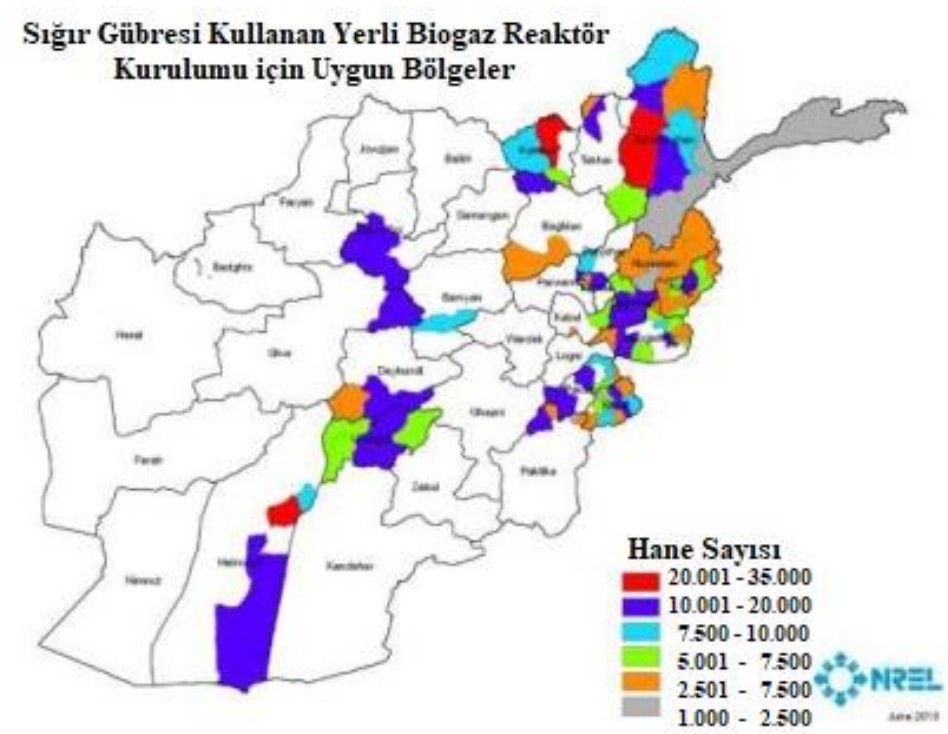

Şekil 4.6. Afganistan'daki hayvansal atıkların üretim bölgeleri (Milbrandt ve Overend, 2011'den uyarlanmıştır)

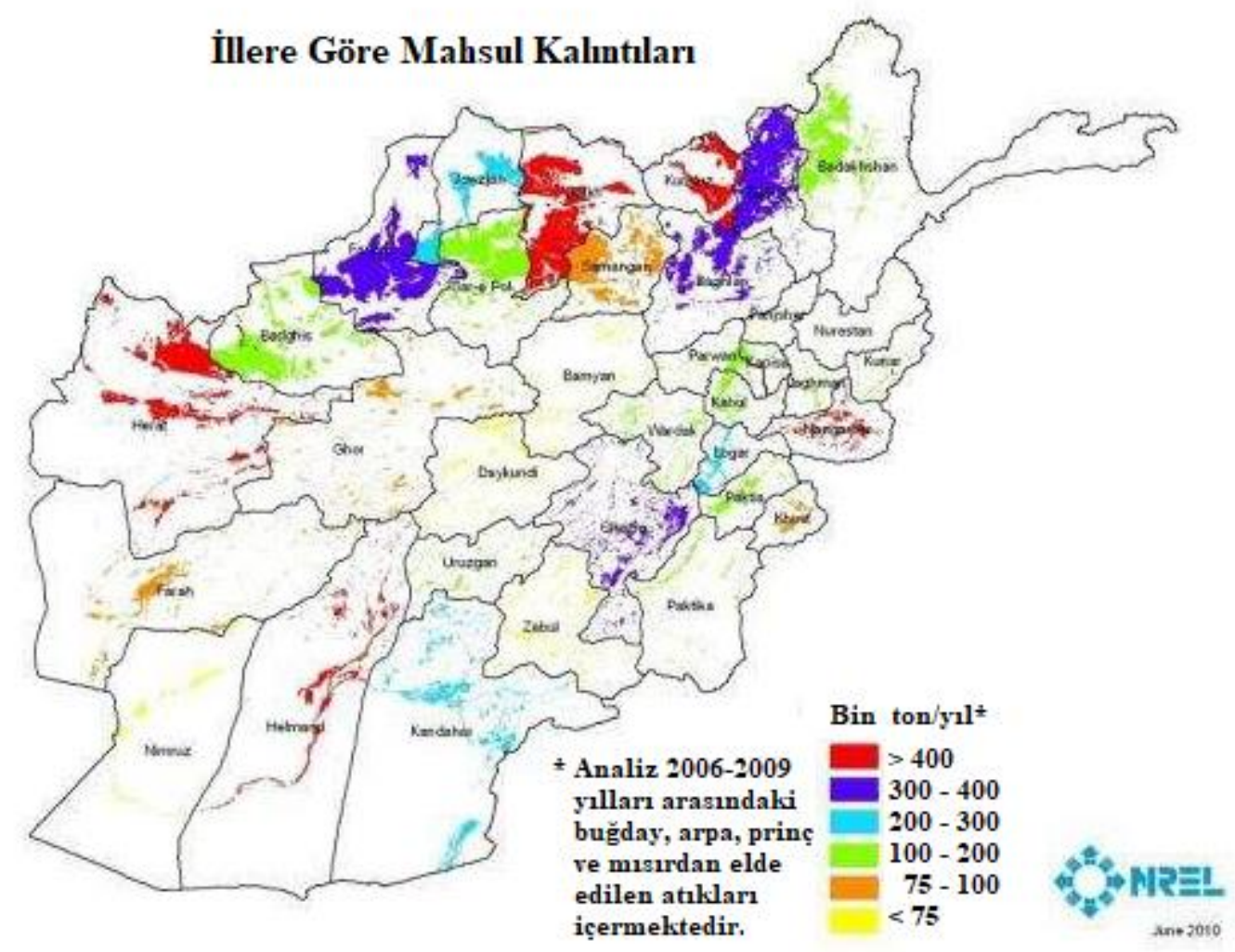


Şekil 4.7. Afganistan'daki mahsul kalıntıların üretim bölgeleri (Milbrandt ve Overend, 2011'den uyarlanmıştır)

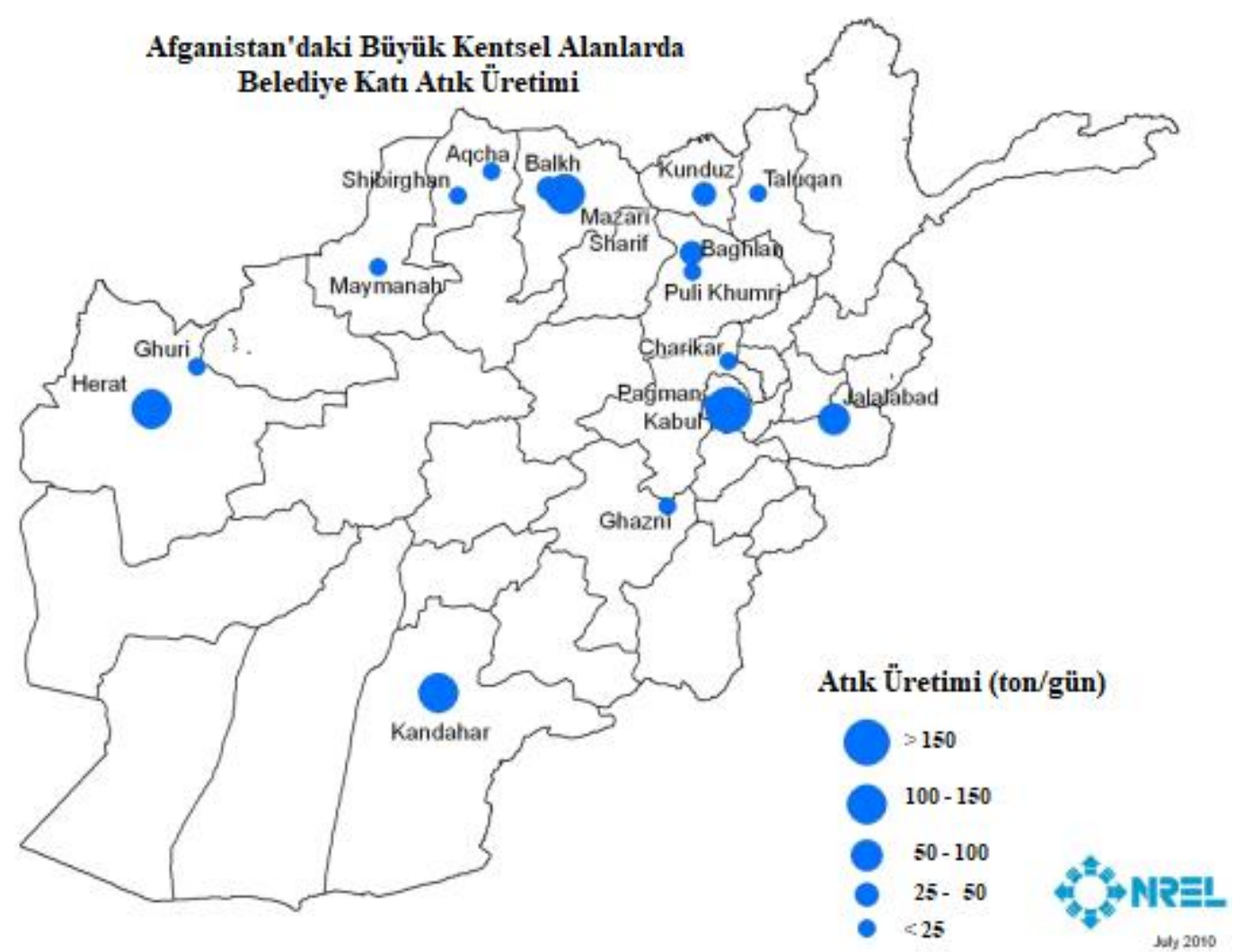

Şekil 4.8. Afganistan'ın illerine göre katı atık üretimi (Milbrandt ve Overend., 2011'den uyarlanmıştır)

\subsection{Afganistan'daki Jeotermal Enerji Potansiyeli}

Afganistan'da enerji üretilebilecek çok yüksek potansiyelde jeotermal kaynağın var olduğu belirtilmektedir (Anonim, 2019a; Anonim, 2019g; Anonim, 2019h). Diğer bir ifadeyle, ülkede elektrik üretmek için jeotermal kaynaklardan yeterli miktarda su veya buhar sağlanabilmektedir (Ludin ve ark., 2017a). Afganistan'da çok eskiden bu yana jeotermal kaynakları çoğunlukla tedavi edici banyo amacı ile kullanılmıştır ve hala önemli oranda kullanılmaktadır. Ludin ve ark. (2017a) tarafından, Hindu Kush bölgesi aktif jeotermal kaynak sistemlerinin ana eksen bölgesine sahip olduğu ve bu sistemlerin Herat ilinde aktif olarak çalıştığı belirtilmektedir. Ayrıca bu çalışmalarda sistemin, ülkenin batı kısmından (Herat) kuzeydoğudaki (Pamir-Afganistan) Wakhan koridoruna kadar uzandığı ve Herat Panjshir'in (doğu'dan batı'ya) çarpıcı coğrafi süturu'nun manto içine $700 \mathrm{~km}$ 'ye kadar derinlikte oturmuş bir indirme-kayma fayı olduğu da ifade edilmektedir. Bazı çalışmalarda benzer bir yapının, Chaman - Moqor (kuzeydoğu - güneybatı) kavis fay sistemi ve diğer ikincil faylar ile ülke genelinde bölgelerin çoğunluğunu kapsadığı da vurgulanmaktadır. (Ludin ve ark., 2017a; Anonim, 2018b; Anonim, 2018c). Saba ve ark. (2004)'na göre, bir jeotermal tesisin kurulması için en az $400 \mathrm{~m}^{2}$ alan gerekmektedir ve böyle bir tesisten 30 yıldan daha fazla elektrik üretilebilmektedir (Ludin ve ark., 2017a). Ülke çapında şu ana kadar jeotermal enerji ile ilgili herhangi bir modern proje yapılmamıştır. Ancak; Ludin ve ark. (2017a) tarafından 70 sahada jeotermal potansiyel kaynak olduğu ve bu sahaların yaklaşık 520 MW arasında kapasiteye sahip olduğu belirtilmiştir. Afganistan'daki mevcut jeotermal 
potansiyeli Şekil 4.9'da gösterilmiştir (Ludin ve ark, 2017a; Anonim, 2018b). 2032 yılına kadar 55 MW elektriğin jeotermal kaynaklardan üretilmesi öngörülmektedir (Anonim, 2017b).

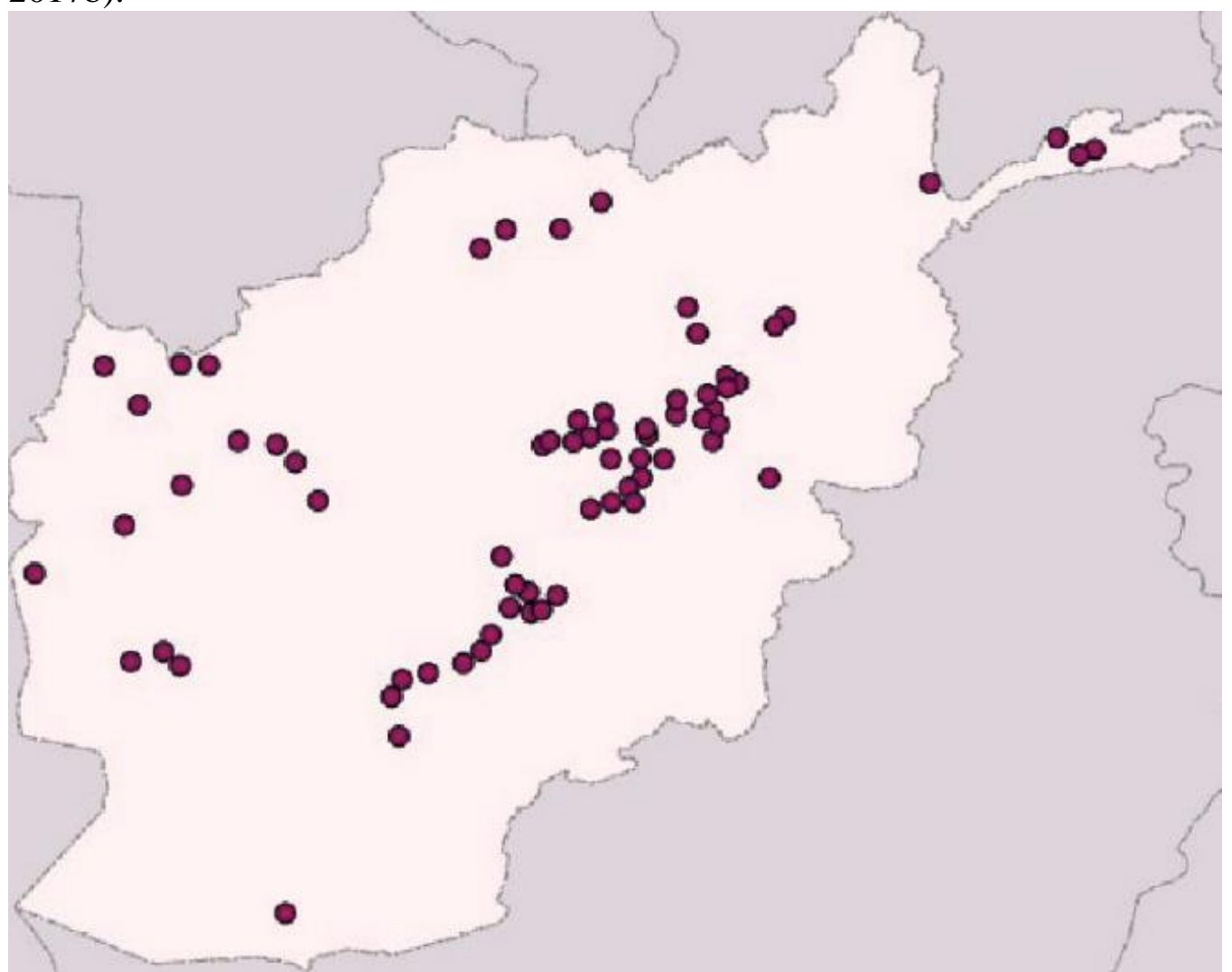

Şekil 4.9. Afganistan'daki jeotermal potansiyel bölgeleri (Ludin ve ark, 2017a; Anonim, 2018b)

\section{Bulgular ve Tartışma}

Günümüzde Afganistan'da, çeşitli nedenlerden dolayı ulusal şebekeden elektrik sağlamak çok zordur. $\mathrm{Bu}$ nedenle, ülkenin enerji talepleri çoğunlukla Asya merkezli ülkelerinden ithal edilmektedir ve bu ülkelerden ithal edilen elektriğin erişimine ulaşmak kolay olmamaktadır. Ayrıca; ülkenin nüfusu çoğunlukla kırsal bölgelerde yaşamaktadır. Mevcut şebekede yaşanan teknik sıkıntılar ve alt yapı sorunları da göz önüne alındığında Afganistan nüfusuna elektrik sağlanması yüksek maliyetli olmaktadır. $\mathrm{Bu}$ nedenle Afganistan hükümeti bu sorunların üstesinden gelebilmek için ülkede potansiyeli yüksek güneş, rüzgar, jeotermal, biyo-kütle ve su kaynaklı yenilenebilir enerji kaynaklarına yönelmeyi hızlandırmaktadır. Ershad (2017) tarafından Afganistan'da, 2013 yılında kişi başına brüt elektrik tüketimi $178 \mathrm{kWh}$ olarak belirtilmiştir. Yapılan çalışmalarda (Anonim, 2017b; Ershad 2017) bu değerin 2020 yılına kadar 500 kWh'a yükselmesi ve 2032 yılına kadar da 650 kWh'a çıkacağı ön görülmektedir. 2011 y1lı için ülkedeki yıllık elektrik talebi Ershad (2017) tarafından 3,531 GWh olarak belirtilmiştir. Bu değer 2032 yılına kadar 18.409 GWh civarında artması ve en yüksek yıllık elektrik talebin 742 MW'tan 3.502 MW'ta ulaşması beklenmektedir (Ershad, 2017). Ershad (2017)'ye göre, 2012 yılı Afganistan nüfusunun \% 25'ten daha azının ulusal şebekeye bağlantısı var iken bu rakamın 2020 yılında \%50'ye ve 2032 y1lında ise \%83'e yükselmesi hedeflenmektedir. Ülkenin toplam kapasitesinin 2032 y1lına kadar 3.500 MW'ın üzerine çıkacağ1 ve bu kapasitenin çoğunlukla hidroelektrik ve güneş gibi yerli enerji kaynaklarından üretilmesinin öngörüldügü kaynaklarda belirtilmektedir (Ludin ve ark, 2016; Ershad, 2017). 
Diğer taraftan, Afganistan'da 2032 yılına kadar yenilenebilir enerji kapasitesinin yaklaşık 5.000 MW'a ulaşacağı ve üretilen elektriğin ülkenin \%95'inin elektrik talebini karşılayabileceği öngörülmektedir (Ershad, 2017). Ayrıca; Afganistan halkının yaşam koşullarında ve refah seviyesinde olası iyileşmelerde dikkate alındığında yenilenebilir enerji kaynaklarından yararlanmaya yönelik daha fazla projeler ve yatırımlar yapılması gerekecektir. $\mathrm{Bu}$ gereksinimler sonucunda şimdiden Afganistan Enerji ve Su Bakanlığ Y Yenilenebilir Enerji Yol Haritasına (YEYH 2032) göre, önümüzdeki on y1l içinde 3.000 MW'lık güneş enerjisi yatırım programının ilk etabı olan 1.500 MW güneş enerjisi projesine başlanacağı ve bu amaçla finansman desteklerin kısmen sağlandığı ifade edilmektedir (Anonim, 2017b).

Elektrik ihtiyacının büyük bir kısmını Türkmenistan, Özbekistan, Tacikistan ve İran gibi komşu ülkelerden ithal etmek zorunda olan Afganistan, ihtiyacının yarıdan daha azını yerli kaynaklarından üretmektedir ve bu üretiminde yenilenebilir enerji kaynaklarının payı oldukça düşüktür. $\mathrm{Bu}$ yerli kaynaklardan üretilen elektrik çoğunlukla hidroelektrik santrallerden sağlanmaktadır. Afganistan'da şu ana kadar yaklaşık 330 MW'lık su kaynağından elektrik üretilmektedir ( Sherzai, 2017; Anonim, 2017c; Anonim, 2018b; Anonim, 2018c). 2032 y1lına kadar toplam 2.720 MW civarında yenilenebilir enerji kaynaklarından elektrik üretimi yapılmasına dair özel yatırımların teşvik edilmesi ve desteklenmesi projeleri üzerinde de çalışıldığı belirtilmektedir (Anonim, 2017b). Afganistan'ın Enerji ve Su Bakanlığı'ndan gelen raporlara göre, 2016 yılında kadar 13 MW kapasite fotovoltaik panellerinin kurularak güneş enerjisinden elektrik üretildiği ve 1,8 MW'lık kapasite tesisin inşa halinde olduğu ifade edilmiştir (Anonim, 2018b). Ayrıca, $12 \mathrm{MW}$ güneş ile rüzgarı ve $100 \mathrm{MW}$ 'lı güneş ile hidrolik hibrit şeklinde inşa aşamasında olduğu ve 2032 yılına kadar 3.000 MW üzerinde güneş enerjisi tesisi kurulacağı vurgulanmaktadır (Anonim, 2017b). Bu çalışmalarda; 2015 yılına kadar yalnız $230 \mathrm{~kW}$ rüzgar enerjisi ve 2017 y1lında 1,7 MW güneş ve rüzgar hibrit şekilde üretim yapıldığı belirtilmiştir. Bu kapasitenin 14 MW'ının Herat ilinde rüzgar enerjisinden sağlandığ 1 ve 36 milyon ABD doları maliyeti olduğu vurgulanmıştır (Anonim, 2016). Afganistan'da elektrik enerjisine ulaşımın gerek teknik ve gerekse ekonomik zorlukları göz önüne alındığında ülkede önemli bir potansiyele sahip olan ve biyokütle kaynakları olarak değerlendirilebilecek hayvan gübreleri, mahsul kalıntılar ve evsel katı atıklar gibi atıkların daha modern ve verimli tesisler kurularak ekonomiye kazandırılması önem taşımaktadır. Alamyar (2014) tarafından belirtildiğine göre; bu kaynaklar mevcut durumda ülke çapında yaklaşık \%80 oranında pişirmek amacıyla ve \%95 üzerinde ise 1sıtma amacıyla kullanılmaktadır. Bu amaçla ülke çapında 350 küçük biyogaz üretim sistemi olduğu Musleh (2016)'nin yaptığı çalışmalardan bilinmektedir. Enerji gereksinimini daha iyi sağlayabilmek ve maliyeti düşürebilmek amacıyla; 2032 yılına kadar 88 MW'lık yeni ve daha modern bir biyokütle tesisin ülke genelinde kurulması projesi Afganistan için büyük önem taşımaktadır. $\mathrm{Bu}$ çalışmalar daha modern ve temiz yaşam alanlarının oluşturulmasına önemli katkılarda sağlayacaktır. Öte yandan bazı çalışmalarda (Ludin ve ark., 2017a; Anonim, 2018b; Anoınim, 2018c); üretim yapılabilir yaklaşık 70 jeotermal kaynağın olduğu tespit edilen ülkede, 5-20 MW arası kapasiteye sahip jeotermal tesislerden yüksek verimde elektrik üretimi olacağ vurgulanmaktadır. Bu sahalardan 2032 yılına kadar en az 55 MW'lık üretim yapılabileceği öngörülmektedir (Anonim, 2017b).

Afganistan'ın 2011'den 2032'ye kadar elektrik talebine yönelik yapılan projeksiyon Şekil 5.1'de ve Şekil 5.2'de gösterilmektedir (Ludin ve ark, 2017a). Bu projeksiyonlar; Afganistan'da enerji yatırımlarına ve özellikle yenilenebilir enerji kaynaklarına daha fazla önem verilmesini çarpıcı bir şekilde göstermektedir. 


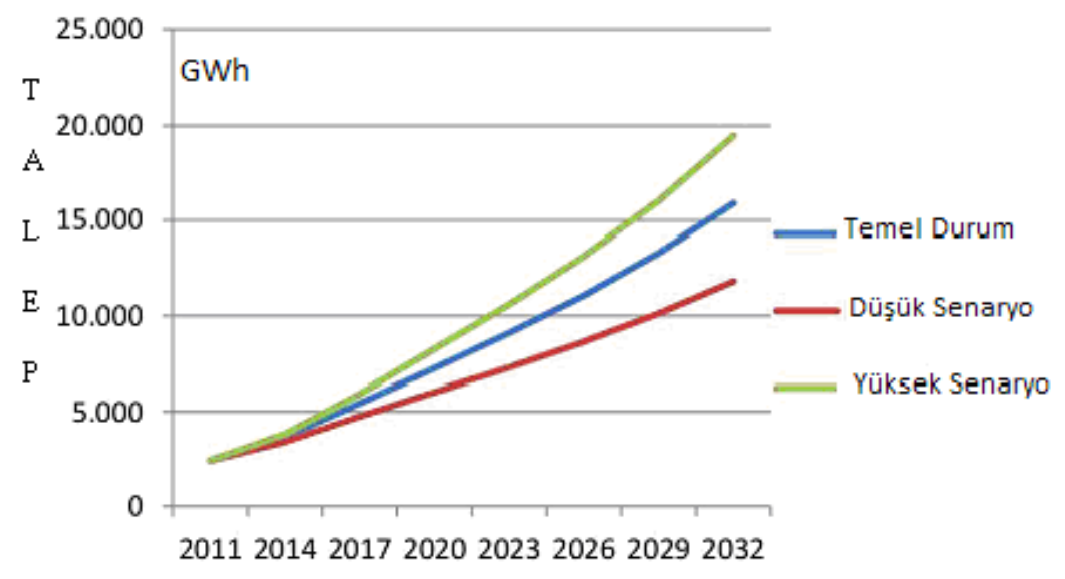

Şekil 5.1. 2032 yılına kadar Afganistan'daki toplam elektrik talebi (Ludin ve ark, 2017a'den uyarlanmıştır)

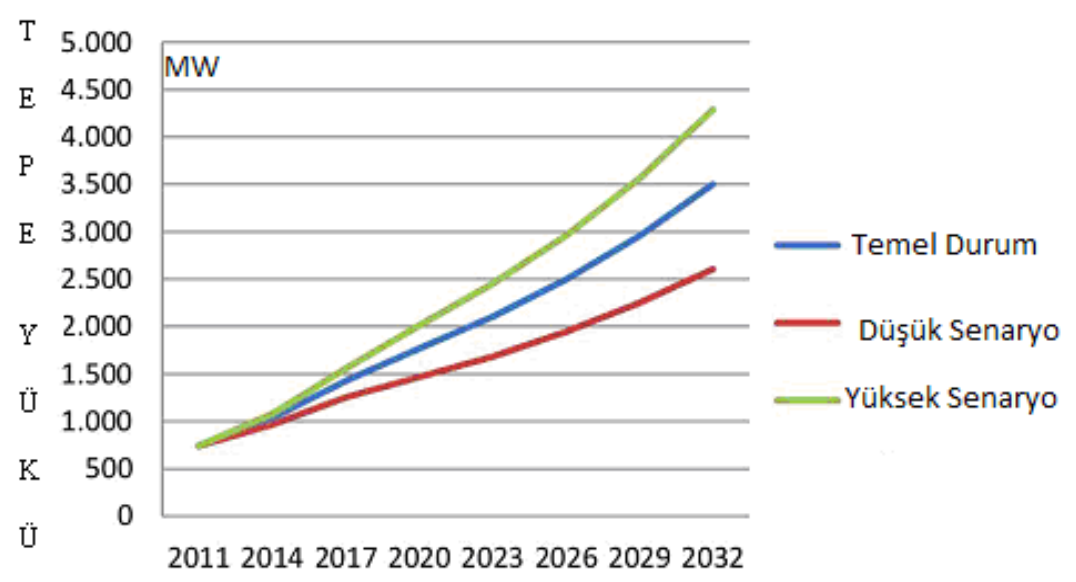

Şekil 5.2. 2032 yılına kadar Afganistan'daki en yüksek elektrik yükü (Ludin ve ark, 2017a'den uyarlanmıştır)

\section{Sonuç}

Afganistan, bulunduğu coğrafi ve jeopolitik konum itibarı ile özellikle güneş, rüzgar, hidrolik, biyokütle ve jeotermal gibi çok önemli yenilenebilir enerji kaynaklarına sahiptir. Ayrıca bu ülkede yenilenebilir enerji kaynaklarının geliştirilmesi için yeterli ve uygun araziler de bulunmaktadır. Afganistan'daki nüfusun büyük çoğunluğu elektrik şebekesinden özellikle ulusal şebekelerden elektrik erişim konusunda mahrum kalmaktadır. Halbuki, yapılan çeşitli çalışmalardan elde edilen bilgiler doğrultusunda, Afgan nüfusu çoğunlukla kırsal bölgelerde yaşayıp ve bu nüfusun \%13'ten daha azı ulusal elektrik şebekelerinden faydalanmaktadır. Bu alanlarda nüfusun \% 80'inden fazlası enerji ihtiyaçlarını odun ve gübre gibi biyokütle atıklarından karşılamaktadır. Ülke çapında nüfusun yaklaşık \% 36'sı yoksulluk sınırı altında olup, bunların çoğu kırsal bölgelerde yaşamaktadır. Afganistan gibi bir ülkede yenilenebilir enerjinin kullanılması sadece elektrik sağlanması konusunda katkıda bulunmaz, aynı zamanda ekonominin ve yaşam koşullarının da iyileştirilmesi ve geliştirilmesi konusunda da özellikle kırsal toplum için büyük bir firsat olacaktır. Ayrıca; bu kaynaklardan elektrik üretimi, iş alanlarının yaratılması ve iş istihdamı konularında büyük katkılar sağlayacaktır. Böylece, binlerce kişi çeşitli işlerde istihdam edilip, işsizlik ülkede kısmen de olsa azalabilecek ve refah seviyesini yükselebilecektir. İşsizliğin azalması ekonomik rahatlığa ulaşılmasını ve 
dolayısı ile refah seviyesinin yükselmesine, böylece savaştan uzak barış dolu müreffeh bir hayata geçilmesini de sağlayabilecektir. Öte yandan yenilenebilir enerji kaynaklarının kullanımı ülkedeki çevre sorunlarının azaltılmasına da yardımcı olabilecektir. Son olarak yenilenebilir enerji kaynaklarından elektrik üretilmesi ülkenin dış enerji bağımlılığını önemli oranda azaltacaktır. Buradan elde edilecek avantajlar ve gelirler ülkenin kalkınmasına daha fazla katkılar sağlayabilecektir. Afganistan coğrafi olarak çok stratejik konumundadır. Yenilenebilir enerji kaynaklarından elde edilebilecek bu yatırım ve başarılar ülkede sanayiyi ve ekonomiyi daha da canlandiracak ve ülke ihracat yapabilir hale gelebilecektir. Pakistan ve Hindistan gibi komşu ülkelere çok büyük bir elektrik kapasitesi ihraç etme potansiyeline sahip iken ve bu ülkelerle iyi bir ticaret yapabilecektir. Tüm bu gelişmeler sonucunda; ülkede yoksulluk azaltılıp, halkın yaşam tarzı ve koşulları iyileşebilecek, böylece ülkenin gelecekteki güvenliğine ve istikrarına katkılar sağlanabilecektir.

\section{Teşekkür}

Yazarlar, Afganistan'daki yenilenebilir enerji kaynakların potansiyeli, önemi ve değeri üzerinde çalışmalar yapan araştırmacılara ve Afganistan Enerji ve Su Bakanlığı'na teşekkür eder. 


\section{Kaynaklar}

Ahmadzai S., McKinna A., 2018. Afganistan electrical energy and trans-boundary water systems analysis: Challenges and opportunities, Energy Repots, 4: 435-469.

Alamyar K.M., 2014. Renewable Energy for Sustainable Development Economic, Policy Directorate Ministry of Economy. 15 Mart 2019, https://ecomod.net/system/files/ECO paper.pdf https://link.springer.com/book/10.1007\%2F978-3-319-92288-1

Anonim, 2013. Afghanistan Rural Renewable Energy Policy, Ministry of Energy and Water, Ministry of Rural Rehabilitation and Development, Afghanistan. 15 Mart 2019, http://www.red-mew.gov.af/

Anonim, 2014a. Renewable Energy Development, Capacity Development Technical Assistance (CDTA), Afghanistan.

15 Mart 2019, https://link.springer.com/content/pdf/10.1007\%2F978-3-319-606217.pdf

Anonim, 2014b. 15 Mart 2019, https://wadsam.com/afghan-business-news/promoting-renewable-energy-in-afghanistan/

Anonim, 2015. Work for Human Development, UNDP Human Development Report 2015. 15 Mart 2019, http://hdr.undp.org/sites/default/files/2015_human_development_report.pdf

Anonim, 2016. Afghanistan Energy Sector. 15 Mart 2019, https://www.unece.org/fileadmin/DAM/energy/se/pp/eneff/7th_IFESD_Baku_Oct.2016 /ESCAP_Elec_CIS/1_W.Aria_AVG.pdf (and see, CSO, Economy Statistics: Mining and Energy. Retrieved from Central Statistics Organization (CSO): Afghanistan Provinical Profile, April 2015, http://cso.gov.af/en 
Anonim, 2017a. Afganistan Coğrafyas1. 27 Mart 2019. https://ipfs.io/ipfs/QmT5NvUtoM5nWFfrQdVrFtvGfKFmG7AHE8P34isapyhCxX/wiki /Afganistan_co\%C4\%9Frafyas\%C4\%B1.html

Anonim, 2017b. Afganistan Ülke Raporu. T.C. Kabil Büyükelçiliği Ticaret Müşavirliği 2017. 27 Mart 2019.

https://www.kutso.org.tr/wp-content/uploads/2017/06/Afganistan.pdf

Anonim, 2017c. Institional Development for Energy in Afghanistan (IDEA) programme Enabling Photovoltaic (PV) Afghanistan, On behalf of the German Federal Ministry for Economic Cooperation and Development (BMZ). 15 Mart 2019, https://www.solarwirtschaft.de/fileadmin/user_upload/report_enabling_pv_afg.pdf

Anonim, 2017d. 15 Mart 2019, http://www.af.undp.org/content/afghanistan/en/home/presscenter/IntheNews/renewableenergy-in-afghanistan-atn.html

Anonim, 2017e. Ülke Profilleri: Afganistan. 27 Mart 2019. https://www.aa.com.tr/tr/ulke-profilleri/afganistan/901494

Anonim, 2018a. Afghanistan-Striving for 100\% Renewable Energy: 15 Mart 2019 http://www.go100percent.org/cms/index.php?id=92\&tx_ttnews\%5Btt_news\%5D=435\& $\mathrm{cHash}=\mathrm{e} 8141 \mathrm{c} 9 \mathrm{~b} 83 \mathrm{~d} 0 \mathrm{~b} 2 \mathrm{f} 847 \mathrm{fc} 5168898 \mathrm{~d} 5 \mathrm{e} 97$

Anonim, 2018b. Report: Afghanistan Renewable Energy Development Issues and Options: 15 Mart 2019, https://openknowledge.worldbank.org/handle/10986/30270

Anonim, 2018c. Human Development Index and its components, United Nations Development Programme (UNDP), Human Development Reports. Table 1. 15 Mart 2019, http://hdr.undp.org/en/composite/HDI

Anonim, 2019a. Coğrafya Dünyas1. 27 Mart 2019. http://www.cografya.gen.tr/siyasi/devletler/afganistan.htm 
Anonim, 2019b. The World Bank in Afganistan. 28 Mart 2019. http://www.worldbank.org/en/country/afghanistan

Anonim, 2019c. Ministry of Mines and Petroleum. 28 Mart 2019. http://mom.gov.af/en

Anonim, 2019d. The World Bank, Data, Afhganistan. 28 Mart 2019. https://data.worldbank.org/country/afghanistan

Anonim, 2019e. The World Bank: Projects \& Operations. 28 Mart 2019. http://projects.worldbank.org/search?lang=en\&searchTerm=\&countrycode_exact=AF

Anonim, 2019f. Dünya Nüfusu: Afganistan Nüfusu. 29 Mart 2019. https://www.nufusu.com/ulke/afganistan-nufusu

Anonim, 2019g. AEIC, Afghan Energy Infoprmation Center, Geothermal Potential in the Structural Domain of the HinduKush in Afghanistan. 15 Mart 2019, http://aeic.af/en/energy_source/3

Anonim, 2019h. Afghanistan Resource Maps. NREL, the US National Renewable Energy Laboratory. 15 Mart 2019, https://www.nrel.gov/international/ra_afghanistan.html

Ashraf A.R., 2009. Energy Sector Afghanistan: Importance of Renewable Energy for Afghanistan, Renewabl Energy for Sustainable Development; International Conference in Dushanba (Tajikistan): 15 mart 2019, https://carnegieendowment.org/files/Presentation_-\%20Ashraf.pdf

Elliott D., 2016. South Asia Regional Initiative for Energy Cooperation and Development (SARI-Energy),Wind Resource Assessment and Mapping for Afghanistan and Pakistan. 15 Mart 2019. https://www.nrel.gov/international/pdfs/afg_pak_wind_june07.pdf and https://pdf.usaid.gov/pdf_docs/PNADO338.pdf 
Ershad A.M., 2017. Institutional and Policy Assessment of Renewable Energy Sector in Afghanistan 15 Mart 2019.

http://downloads.hindawi.com/journals/jre/2017/5723152.pdf

Fahmi A., Upham, P., 2017. The renewable energy sector in Afganistan: Policy and potential, Wiley Interdisciplinary Rewievs: Energy and Environment,WIREs, Vol. 7, Issue 2, pp. $1-9$

Ludin G.A., Amin M.A., Aminzay A., Senjyu T., 2017a. Theoretical Potential and Utilization of Renewable Energy in Afghanistan, AIMS Energy, Vol. 5, pp1-19. 15 Mart 2019, http://www.aimspress.com/article/10.3934/energy.2017.1.1. And ADB (2013) Power sector master plan, Technical Assistance Consultants Report. Islamic Republic of Afghanistan: Project Number 43497. 04 Nisan 2019.

https://www.adb.org/sites/default/files/project-document/76570/43497-012-afg-tacr.pdf

Ludin G.A., Matayoshi H., Danish M.S.S., Yona A., Senjyu T., 2017b. Hybrid PV/Wind/Diesel Based Distributed Generation for an Off-Grid Rural Village in Afghanistan. Journal of Energy and Power Engineering, Vol. 11, pp. 85-94.

Milbrandt A., Overend R., 2011. Assessment of Biomass Resources in Afghanistan, National Reneable Energy Laboratory (NREL). 15 Mart 2019. https://www.nrel.gov/docs/fy11osti/49358.pdf

Musleh A.J., 2016. Renewable Energy Department, SAARC Work shop on Application of on-grid Biogass Technology, Ministry of Energy and Water, Kabul Afghanistan. 15 Mart 2019. http://www.saarcenergy.org/wp-content/uploads/2016/07/ Afghanistan\%20presentation.pdf

Nasrati A.A., 2015. Sustainable Energy for All Afghanistan, SE4ALL Consultation Workshop. 15 Mart 2019. https://d2oc0ihd6a5bt.cloudfront.net/wp-content/uploads/sites/837/2015/06/AhmadAbdullah-Nasrati_Afghanistan.pdf 
Saba D.S., Najaf M.E., Musazai A.M., ve ark., 2004. Geothermal Energy in Afghanistan, Prospects and Potential. New York, USA. \& Afghanistan Center for Policy and Development Studies, New York University Kabul, Afghanistan

Samadi A.R., 2011. Energy Consumption and Available Energy Resources in Afghanistan, Da Afghanistan Breshna Sherkat.

19 Nisan 2019. https://www.usea.org/sites/default/files/event-file/522/Afghan_Power_ Sector_Briefing_June_2011.pdf

Sherzai A., 2017. Energy Experts of the Future: Afganistan. UNDP. 15 Mart 2019, http://www.af.undp.org/content/afghanistan/en/home/ourwork/environmentandenergy/s uccessstories/energy-experts-of-the-future.html

Snallen W.B., Schravel A., 2004. Working with farmers, 15 Mart 2019, http://www.newatereducation.nl/file.php/1/HowToTeach/AlterraRapport1096-1.pdf 